\title{
Getting Our Priorities Straight: One Strand of the Regulatory Reform Debate
}

\author{
David M. Driesen*
}

This paper can be downloaded from the Social Science Research Network Electronic Paper Collection: http://papers.ssrn.com/paper.taf?abstract_id=245638

\footnotetext{
* Associate Professor, Syracuse University College of Law, J.D. Yale Law School 1989.
} 
Several prominent academic critics of regulation, most notably Cass Sunstein and Stephen

Breyer, claim that our regulatory system does not establish sensible priorities. ${ }^{1}$ Their reform

recommendations seek to correct this problem - to get our priorities straight.

What precisely does it mean to say that we do not have our priorities straight? This article

develops a theoretical framework to address this question.

This strand of the regulatory reform debate matters a lot. Congressional and academic

proponents of regulatory reform have relied heavily upon claims that the regulatory system fails to

establish sensible priorities to justify more reliance upon cost-benefit considerations in agency decision-

making. ${ }^{2}$ The goal of improving priority setting sounds much more attractive than the goal many

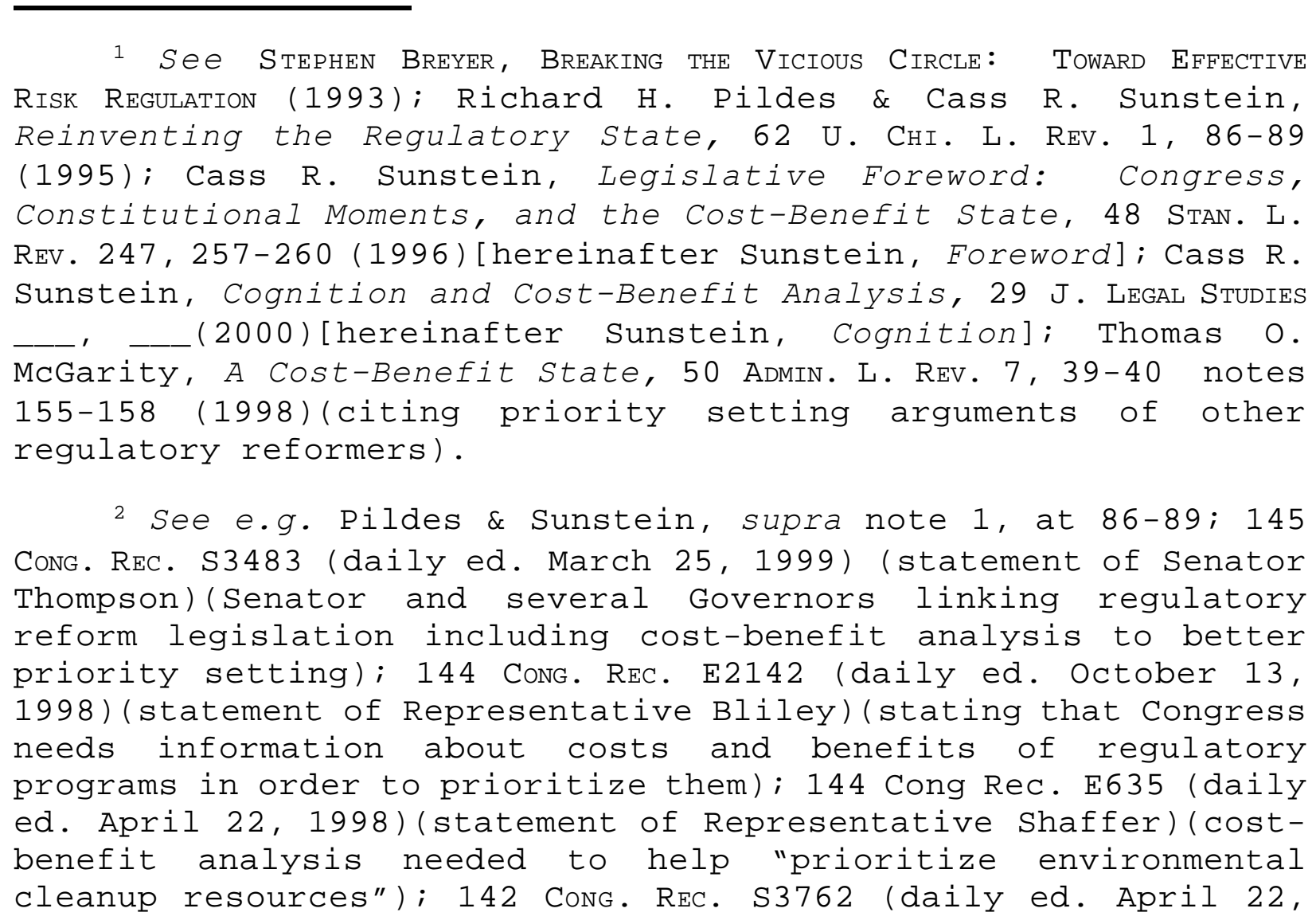


knowledgeable scholars link to cost-benefit analysis (CBA), the reduction of the stringency and scope

of laws protecting public health and the environment. ${ }^{3}$ So reliance upon priority setting talk helps CBA

politically, giving it a neutral aura. After more than two decades of writing legislation that made

protection of public health the primary goal of much of the regulatory system, ${ }^{4}$ the 104 th Congress

1996) (statement of Senator Smith) (we must incorporate costbenefit analysis in our environmental regulations in order to "prioritize our goals."); 141 Cong. REc. S17744 (daily ed. November 29, 1995) (statement of Senator Bond) (stressing CBA as it relates to budget priorities because "that is the only way. - to get the biggest bang for the buck"); 141 Cong. Rec. H12007 (daily ed. November 9, 1995) (statement of Representative Clinger) (stating that cost-benefit provisions in regulatory reform legislation requires the prioritization needed because of limited federal resources).

3 See e.g. McGarity, supra note 1, at 11 (cost-benefit analysis "will invariably reduce the protections that the existing statutes currently afford to citizens and the environment."); Thomas O. McGarity, The courts and the Ossification of Rulemaking: A Response to Professor Seidenfeld, 75 Tex. L. Rev. 525, 541-549 (1997) (explaining how a cost-benefit requirement and hard look judicial review ended regulation under section 6 of the Toxic Substances Control Act).

4 See e.g. Natural Resources Defense Council (NRDC) V. EPA, 824 F.2d 1146 (D.C. Cir. 1987) (in banc) (interpreting requirement that EPA regulate toxic air pollutants to provide an ample margin of safety to public health); Lead Industries Ass'n $v$. EPA, 647 F.2d 1130 (D.C.Cir. 1980), cert. denied, 449 U.S. 1042 (1980) (forbidding consideration of cost in establishing national ambient air quality standards to protect public health); Public Citizen V. Young, 831 F.2d 1108, 1112 (D.C. Cir. 1987) (primary goal of Food Drug and Cosmetic Act is "human safety"); American Textile Manuf. Inst. Inc. v. Donovan, 452 U.S. 490, 540 (1981) (goal of statute is to advance worker health, unless doing so is unfeasible; CBA rejected). Cf. Corrosion Pipe Fittings v. EPA, 947 F.2d 1201 (5th Cir. 1991) (applying a cost-benefit test to regulation of the manufacturing of toxic substances); Union Electric V. EPA, 427 U.S. 246, 266 (1976) (States may consider costs in choosing strategies for meeting national ambient air 
passed the Unfunded Mandates Reform Act of $1995,{ }^{5}$ which requires CBA of major rules. ${ }^{6}$ Since then, Congress has regularly considered, and come close to passing, regulatory reform legislation that requires agencies to justify substantially all major regulation in cost-benefit terms. ${ }^{7}$ This involves a major change in the goals of statutes that have hitherto sought to protect public health and the environment. ${ }^{8}$ In general, industry has enthusiastically supported CBA and environmentalists and quality standards).

5 Pub. L. No. 104-4; 109 Stat. 48 (codified in scattered sections of 2 U.S.C.). See generally Rena Steinzor, Unfunded Environmental Mandates and the "New Federalism": Devolution, Revolution or Reform, 81 Minn. L. Rev. 97 (1996).

6 Id. $\$ 202$, codified at 2 U.S.C. $\$ 1532$.

7 See e.g. Job Creation and Wage Enhancement Act of 1995, H.R. 9, 104th Cong. \$ 422 (1995); Comprehensive Regulatory Reform Act of 1995, S. 343, 104th Cong. \$ 623 (1995) (as introduced in February, 1995). For reviews of the regulatory reform legislation in recent Congresses see William F. Buzbee, Regulatory Reform or Statutory Muddle: The "Legislative Mirage" of Single Statute Regulatory Reform, 5 N.Y.U. Envti. L. J. 298 (1996) (reviewing amended versions of H.R. 9 and S. 343); NATURAL Resources Defense Council (NRDC), Breach of Faith: How the Contract's Fine PRINT Undermines AMERICA'S ENvironmental SucCess (1995) (primarily focused on H.R. 9); Victor B. Flatt, Environmental "Contraction" for America? (Or How I Stopped worrying and Learned to Love the EPA), 29 Loy. L.A. L. Rev. 585 (1996); Jerry L. Mashaw, Reinventing Government and Regulatory Reform: Studies in the Neglect and Abuse of Administrative Law, 57 U. PItr. L. Rev. 405 (1996); Sunstein, Foreword, supra note 1, at 272-286; NRDC, Aт тне Crossroad: environmental threats and Opportunities in the $106 \mathrm{TH}$ Congress (2000); NRDC, Backdoor Legislating: a Status Report on the Environment and the 106 th CONGRess; NRDC, Damage RePort: Environment and the 105 th CONGRess (1998); NRDC, Still in the Woods: Congress' Continuing attack on the ENVIRONMENT (1996).

8 See David M. Driesen, The Societal Cost of Environmental Regulation: Beyond Administrative Cost-Benefit Analysis, 24 
consumer advocates have opposed it. ${ }^{9}$ Academics and policy-makers who support CBA as a means of improving priority setting have never explained why CBA influences priority setting, let alone improves it. A coherent theory of priority setting helps clarify the precise meaning of priority setting claims. This clarification aids evaluation of claims that regulatory priorities are seriously askew and that CBA helps cure priority setting defects.

This article claims that regulatory reformers infer priority defects from evidence of allocative inefficiency. This helps explain (but not justify) some reformers' endorsement of CBA as a priority setting mechanism. Regulatory reformers' use of improved priority setting as a metaphor for improved allocative efficiency obscures the issues at stake in the regulatory reform debate. Priority setting talk allows scholars and legislators to advocate a reform that addresses the stringency of regulation, while giving the impression that something as innocuous as an ordering of tasks is at stake.

ECOLOGY L. Q. 545, 554-558, 560-563 (1997) (explaining how a costbenefit criterion would change existing environmental law); Thomas O. McGarity, The Expanded Debate Over the Future of the Regulatory State, 63 U. CHI. L. Rev. 1463, 1463 (1996) (describing regulatory reform as involving "radical changes" to regulatory statutes); Sunstein, Foreword, supra note 1, at 253-257 (suggesting that regulatory reform might constitute a "constitutional moment" if it went far enough).

9 See Gregory S. Wetstone, And Now, Regulatory Reform, N.Y. Times, Feb. 23, 1995, at A23 (characterizing House regulatory reform as "a recipe for gridlock."); Regulatory Reform: Hearings Before the Senate Comm. on Governmental Affairs, 104th Cong. 122 (1995) (statement of Linda Greer, Ph.D., Senior Scientist, Natural Resources Defense Council) (explaining that "those with the most money to develop information" can use risk assessment to slow down the regulatory system); McGarity, supra note 1 , at 34 . 
This article first develops a theoretical framework describing priority setting. The second part maps out the law of priority setting, emphasizing examples from the law of pollution control. Amazingly, regulatory reform advocates have made their recommendations for improving priority setting in a legal vacuum, with no discussion of the priority setting mechanisms that now exist. The third part examines Breyer and Sunstein's claim that regulatory priorities are seriously askew. The fourth part critiques the claim that CBA will improve priority setting.

Clarity about the concept of priority setting yields conclusions with important implications for the regulatory reform debate. We do not yet know whether we have a serious priority setting problem. If we have a problem, cost-benefit analysis of standard setting does nothing to address it.

\section{Priority Setting: A Conceptual Framework}

The word "priority" comes from the Latin word "prior."10 "Prior" refers to the earlier or first of several items, although it has also referred to the most important of a number of things. ${ }^{11}$

Strictly speaking, priority setting involves establishing an ordering of some kind. Ordering implies that we plan to complete several tasks, but we lack the resources to tackle them all at once, so we accomplish them in rank order.

We commonly use the term priority setting a little less strictly to refer to decisions about performing some tasks while leaving others undone. This mode of priority setting, selection, involves a value judgment, in the context of limited resources, that some tasks are not worth doing.

\footnotetext{
10 See The Compact Edition of the Oxford English Dictionary 1383 (1971).

11 See id.
} 
We also make decisions to devote more of our time (or some other resource, like money) to one set of tasks rather than another. Some allocative decisions might function as secondary priority setting decisions. We may unintentionally affect selection or ordering of tasks by decisions about resource allocation. Hence, for example, we may counsel a young father to spend less money on restaurant meals, because we fear that he will not save enough money to pay for his children's education. We may fear that a resource allocation decision may result in unintentional selection, a tacit decision not to educate his child after high school. I will refer to allocation decisions that affect ordering or selection as allocative priority setting.

Some allocation decisions, however, have little impact upon ordering or selection. We may have decided that one task is more important than another. We conclude from this that we must do a better job at a high priority task than at a low priority task. We therefore allocate more resources to the high priority task. We might refer to this as a "performance allocation," since this type of allocation involves a decision to perform some tasks better than others. Perfectionists reject performance allocation altogether.

We might allocate more time to some tasks, however, precisely because we intend to perform all tasks equally well. Some tasks require more resources than others, because of the nature of the task. Hence, a lawyer may devote more time to an anti-trust case than a simple divorce, because a competent trial of an anti-trust issue may simply require more preparation than a competent trial of a divorce issue. We might refer to this as "difficulty allocation," trying to match resources to the difficulty of the task at hand. A difficulty allocation assumes an equal commitment to a set of tasks. This equal 
commitment bespeaks a decision not to set priorities among the tasks at hand. This means that some resource allocation decisions involve priority setting and others do not.

We sometimes fail to carry out all of our tasks perfectly in spite of good priority setting. This means that one cannot judge somebody else's priorities by looking at the results they produce alone. A person may fail to complete a task, for example, because she could not accomplish it, not because she assigned it a low priority. So, for example, a law student may fail a class, not because she failed to devote sufficient time to her studies, but because she could not understand the material. We cannot infer anything about ordering, selection, or allocation of resources directly from results. We must examine priority setting and allocation directly.

Regulatory reformers focus upon regulatory priority setting. ${ }^{12}$ Hence, a conceptual framework must address the priorities of organizations, not just individuals. The basic concepts of ordering, selection, and allocation will still prove useful, but the more complex context demands some elaboration.

Because administrative agencies consist of people who devote time to tasks, analysis of agency priority setting might be directly analogous to individual priority setting decisions-decisions about how to spend our time. Agency decisions, however, often have broad ramifications.

The product of agency decision-making, a legally binding decision, often requires regulated firms to spend their money. ${ }^{13}$ This means that agency decisions usually affect allocation decisions at regulated firms. So, a clear regulatory reform debate must specify whose resources are at stake.

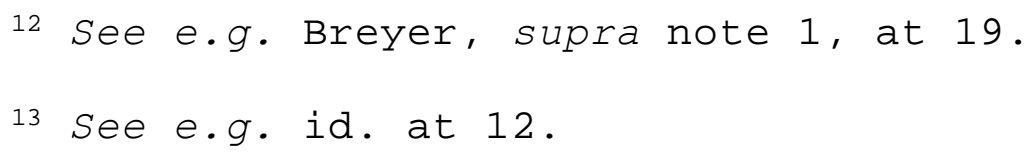


Regulatory reformers often lament the "misallocation" of "social resources."14 This reference to "social resources" contains an important ambiguity. It does not specify whose resources have been misallocated, the government's or those of the private firms it regulates. ${ }^{15}$ And it does not explain clearly whose priorities must be set straight.

Administrative agencies do not have complete control of their activities. Administrative agencies carry out mandates in legislation that Congress passes with funds that Congress appropriates. This means that analysts must distinguish between administrative and Congressional priority setting. ${ }^{16}$ Agencies, like individuals, often fail to carry out their tasks well because of external pressures. ${ }^{17}$ For this reason, we can not tell much about priority setting from agency performance without some direct analysis of agency priory setting. For example, if an agency decides to regulate a very harmful

14 See Pildes \& Sunstein, supra note 52 (discussing goal of ensuring that "social resources are devoted to the most serious problems.").

15 See e.g. Victor B. Flatt, Should the Circle be Unbroken?: A Review of the Hon. Stephen Breyer's Breaking the Vicious Circle: Toward Effective Risk Regulation, 24 Envt'L. L. 1707, 1716 (1994) (Breyer fails to consider the distinction between government and private party costs).

16 See generally Howard Latin, Ideal Versus Real Efficiency: Implementation of Uniform Standards and "Fine-Tuning Regulatory Reforms, 37 STAN. L. Rev. 1267, 1290 (1985) (regulatory reformers should distinguish between claims that Congressional goals are wrong with claims that its goals can be achieved more cost effectively)

17 See id. at 1292-1293; Thomas O. McGarity, Not So Paradoxical: The Rationale for Technology-Based Regulation, 1991 Duke L. J. 729, 736-739. 
substance in gasoline, but a court enjoins it from doing so, we would be wrong to infer that the agency chose its priorities poorly by not regulating the harmful substance. ${ }^{18}$

As we go about our daily lives, we may not think about priorities in such explicit terms. But if we want to counsel an individual on how to get his priorities straight, we might do well to bear these different types of priority setting in mind, even if these modes of priority setting overlap. Scholars should be no less precise as they provide advice about reforming institutions addressing important social problems.

Clearly, priority setting can have many meanings. And the distinctions between various kinds of priority setting have important implications.

\section{The Law of Priority Setting}

This section maps out the legal landscape of priority setting. This discussion uses the law of pollution control to illustrate the concepts of ordering, selection, and allocation, rather than provide comprehensive coverage of all of the law of priority setting.

\section{A. Ordering}

Many pollution control problems stem from a large variety of pollution sources. ${ }^{19}$ Resource limitations generally preclude regulating every important pollution source at once.

Congress often sets (or authorizes agencies to set) early deadlines for large pollution sources and later deadlines (or no deadlines) for relatively small sources of a group of pollutants targeted for

\footnotetext{
18 See Ethyl Corp. v. EPA, 51 F.3rd 1053 (D.C. Cir. 1995) (striking down an EPA ban on manganese in gasoline).

19 See Driesen, supra note 8, at 582 .
} 
regulation. $^{20}$ Thus, for example, section 112 of the Clean Air Act (CAA) requires EPA to establish regulations for major sources of hazardous air pollutants, but requires regulation of smaller "area sources" according to a later schedule. ${ }^{21}$ Congress imposed deadlines upon state regulation of major sources of conventional air pollutants in areas with dirty air, while leaving regulation of smaller sources subject to no specific deadline. ${ }^{22}$ Similarly, Congress required technology-based standards for point sources of water pollution, often large manufacturing facilities, while leaving regulation of non-point sources (such as farms) to subsequent state action. ${ }^{23}$

In establishing priorities among clean-up tasks involving mixes of pollutants Congress often orders regulation by risk, rather than size. For example, the Comprehensive Environmental Responsibility and Cleanup Act (CERCLA) ${ }^{24}$ requires EPA to establish a national priorities list of "superfund sites" (sites where hazardous waste has been dumped) based on the relative risks the sites

20 See e.g. National Mining Ass'n V. EPA, 59 F.3rd 1351, 1353-1354 (D.C. Cir. 1995) (discussing the CAA's differential treatment of major and "area" pollution sources).

21 See 42 U.S.C. \$ 7412 (c) (1), (3); (e)(1).

22 See 42 U.S.C. \$ 7511 a (b) (1) (A), (2) (C); (c), (d), (e) .

23 See 33 U.S.C. \$ 1311; Oliver A. Houck, Are We There Yet?: The Long Road Toward Water Quality-Based Regulation Under the Clean Water Act, 27 ELR 10391 (Aug. 1997).

2442 U.S.C. \$ 9601 et seq. 
pose to public health and the environment. ${ }^{25}$ CERCLA generally anticipates earlier clean-up of high priority sites. ${ }^{26}$

Sometimes Congress combines size and toxicity to order a set of tasks. For example, section 112 of the CAA authorizes EPA to consider both toxicity, quantity, and location in establishing a schedule for regulation of major sources of hazardous air pollution. ${ }^{27}$ Similarly, legislation banning disposal of waste on land under the Resource Conservation and Recovery Act (RCRA) requires EPA to implement the ban in phases. ${ }^{28}$ RCRA instructs EPA to consider both "high volume" and intrinsic hazard" in establishing a schedule. ${ }^{29}$

Congress, however, recognized that rank ordering priorities under RCRA and the CAA could involve EPA in litigation before any clean-up occurred and exempted EPA's scheduling decisions regarding the land ban and regulation of major air toxics sources from judicial review. ${ }^{30}$ Congress has recognized that ordering decisions can prove controversial and generate major delays, but do not themselves provide any public benefits. Since no benefits occur until the agency promulgates rules

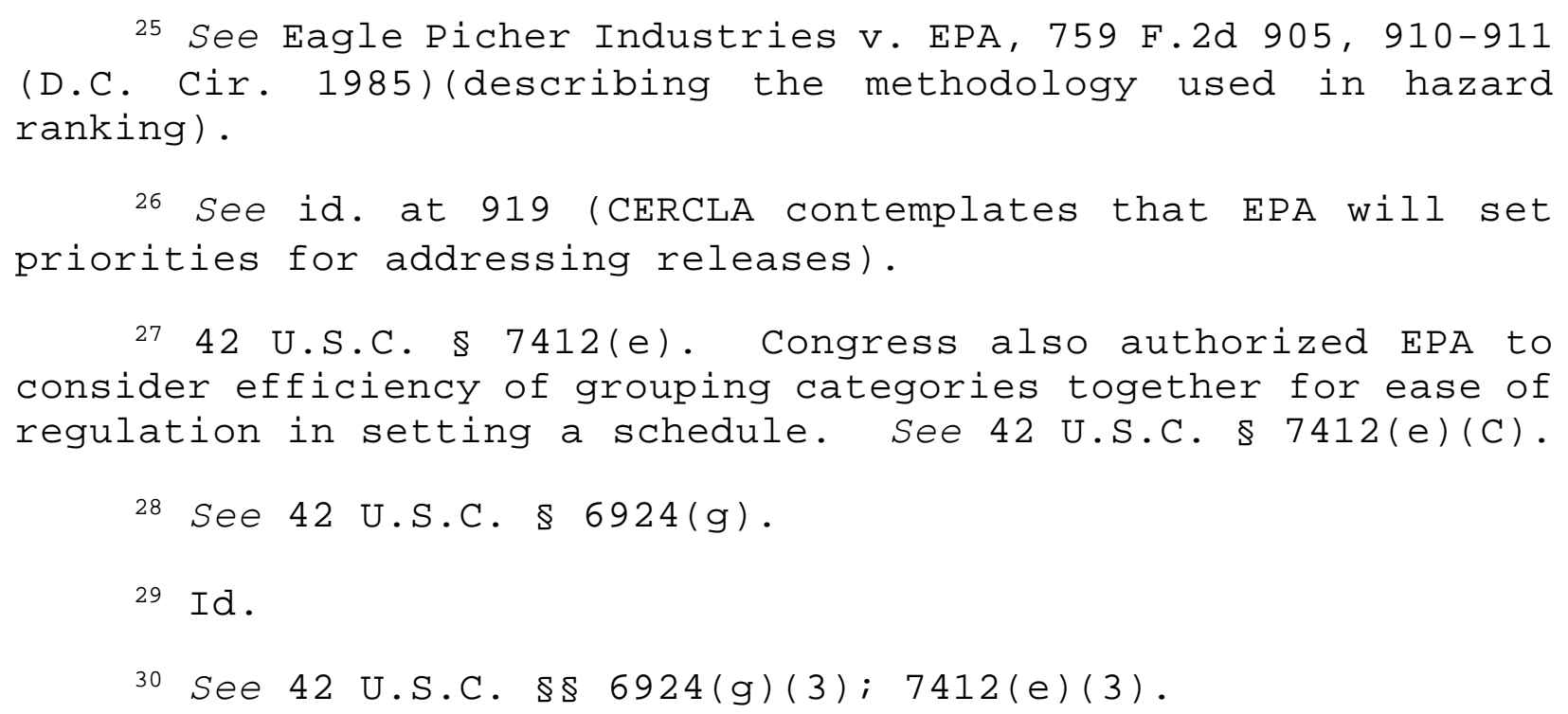


regulating the sources on a schedule, Congress has sometimes sought to avoid litigation of the

preliminary ordering step.

\section{B. Selection}

Perhaps the most important priority setting decisions in environmental law involve the selection of pollutants for regulation. ${ }^{31}$ Either Congress or an administrative agency identifies some substance that must be regulated and leaves other substances unregulated. ${ }^{32}$

Many of the major environmental statutes authorize EPA to list harmful pollutants for regulation. ${ }^{33}$ Usually, EPA may list pollutants for regulation without firm proof of harm, because Congress intended environmental regulation to prevent harms even in the face of scientific uncertainty. ${ }^{34}$

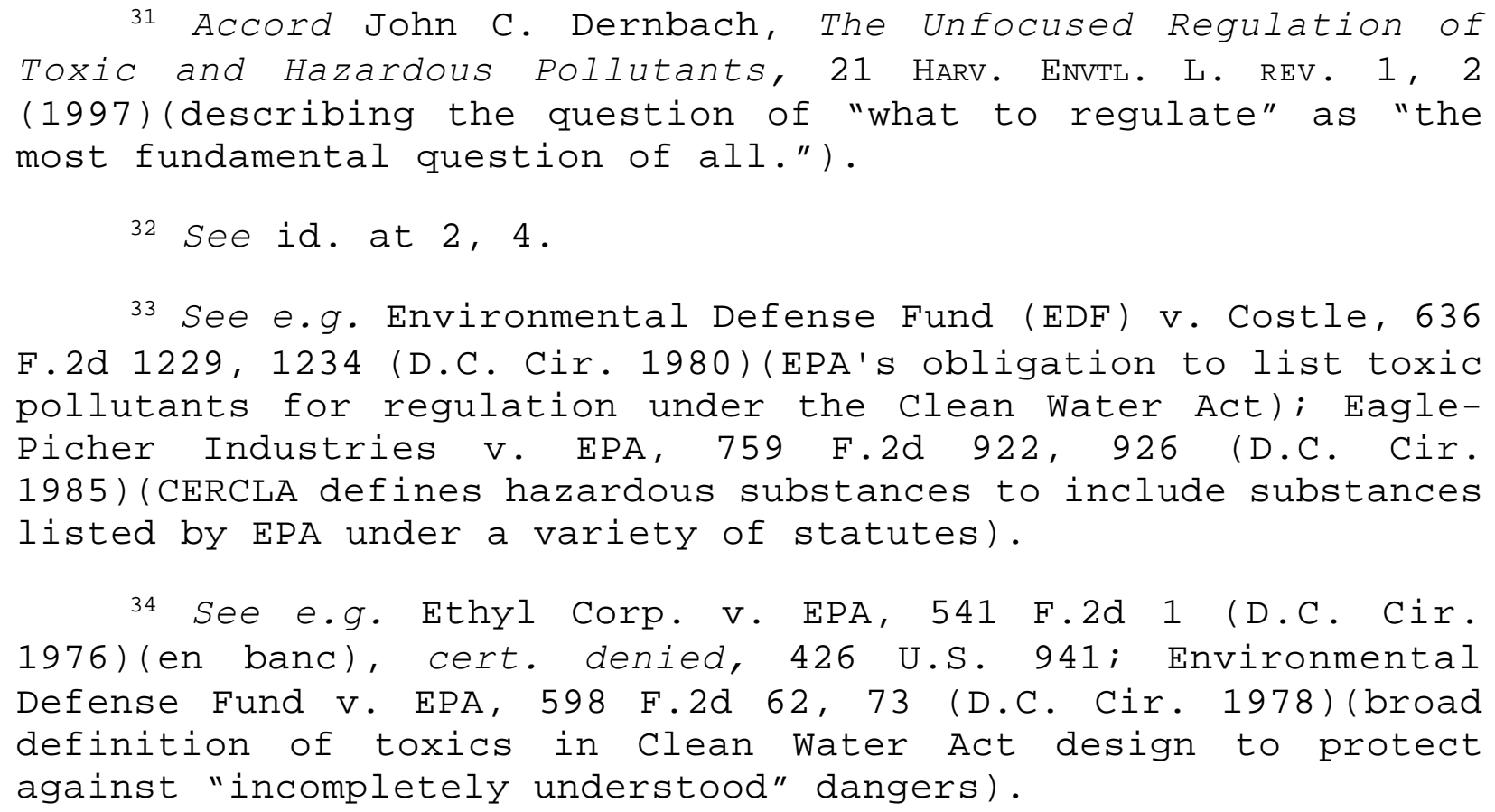


For example, the 1970 Amendments to the Clean Air Act authorized EPA to regulate pollutants which "in his judgment has an adverse affect on public health." ${ }^{35}$ The D.C. Circuit in dicta indicated that this language required a showing of actual health effects and prohibited precautionary listing based on possible dangers. ${ }^{36}$ Congress promptly amended the Act to affirm EPA's authority to make precautionary listing decisions, authorizing listing of pollutants that "cause or contribute to air pollution which may reasonably be anticipated to endanger public health or welfare." ${ }^{97}$ EPA eventually listed six "criteria" pollutants for state regulation, sulfur dioxide, particulate matter, carbon monoxide, ozone, and nitrogen oxide. ${ }^{38}$ The Clean Water Act also uses a precautionary approach, simply requiring EPA to consider a pollutant's toxicity, persistence, degradeability, and it potential affect on organisms in the water in deciding whether to list a particular toxic pollutant for regulation. ${ }^{39}$

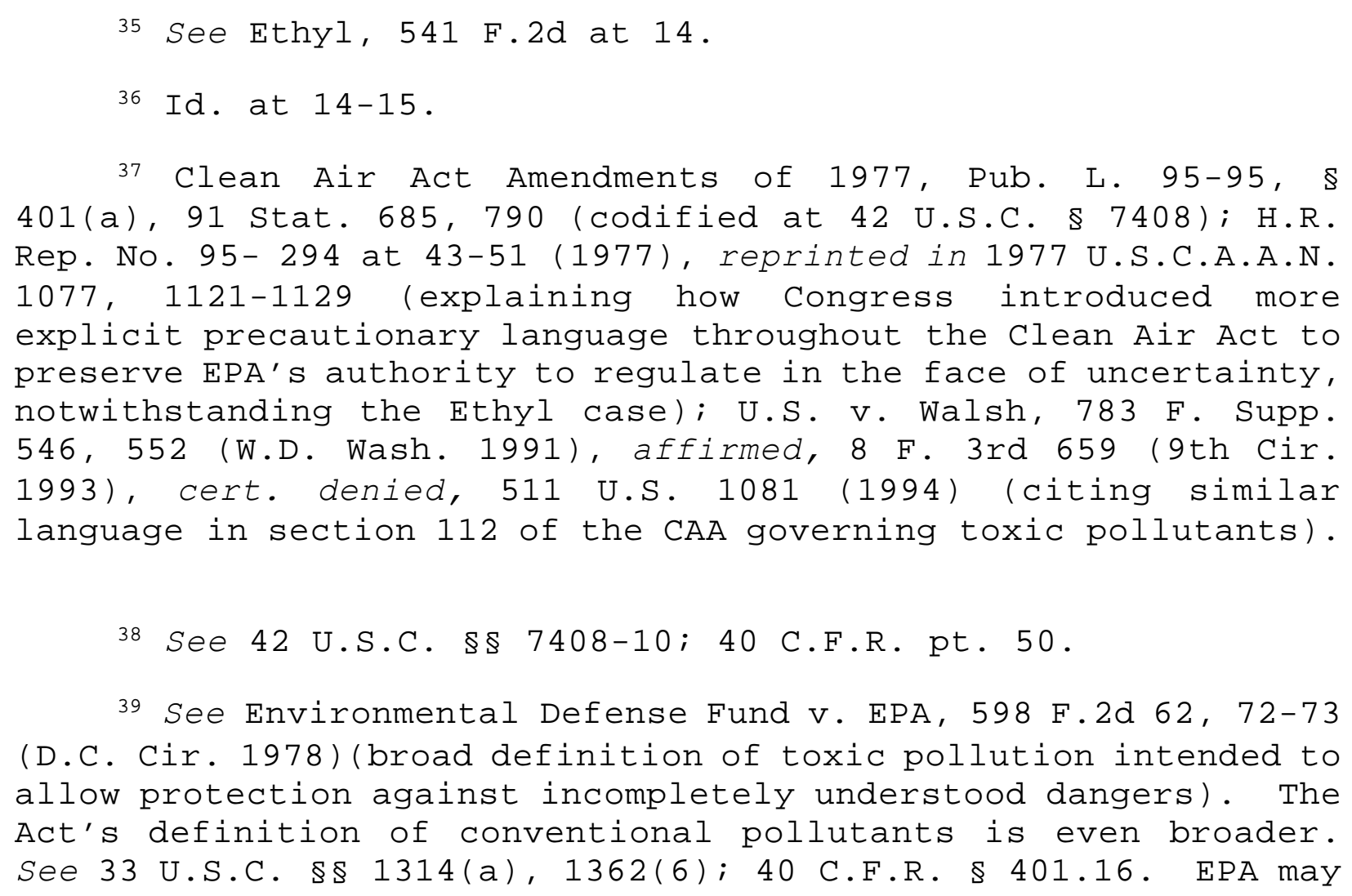


Similarly, RCRA allows EPA to regulate hazardous waste through use of general characteristics associated with health effects, rather than proof that a particular substance harms human health. RCRA requires the promulgation of characteristics of hazardous waste. ${ }^{40}$ This takes into account toxicity, but it also takes into account persistence, degradeability, potential for accumulation in tissue, flammability, corrosiveness, and "other hazardous characteristics." 41 This open-ended criteria has led to the promulgation of a fairly long list of hazardous wastes and a general test private parties must apply to wastes that the agency itself has not listed (or even considered). ${ }^{42}$

In spite of Congressional support for a precautionary approach to listing, agency listing often proceeds slowly. The 1972 Federal Water Pollution Control Act (FWPCA) required EPA to list toxic pollutants and regulate them within 90 days. ${ }^{43}$ EPA listed only nine pollutants under this section (over a

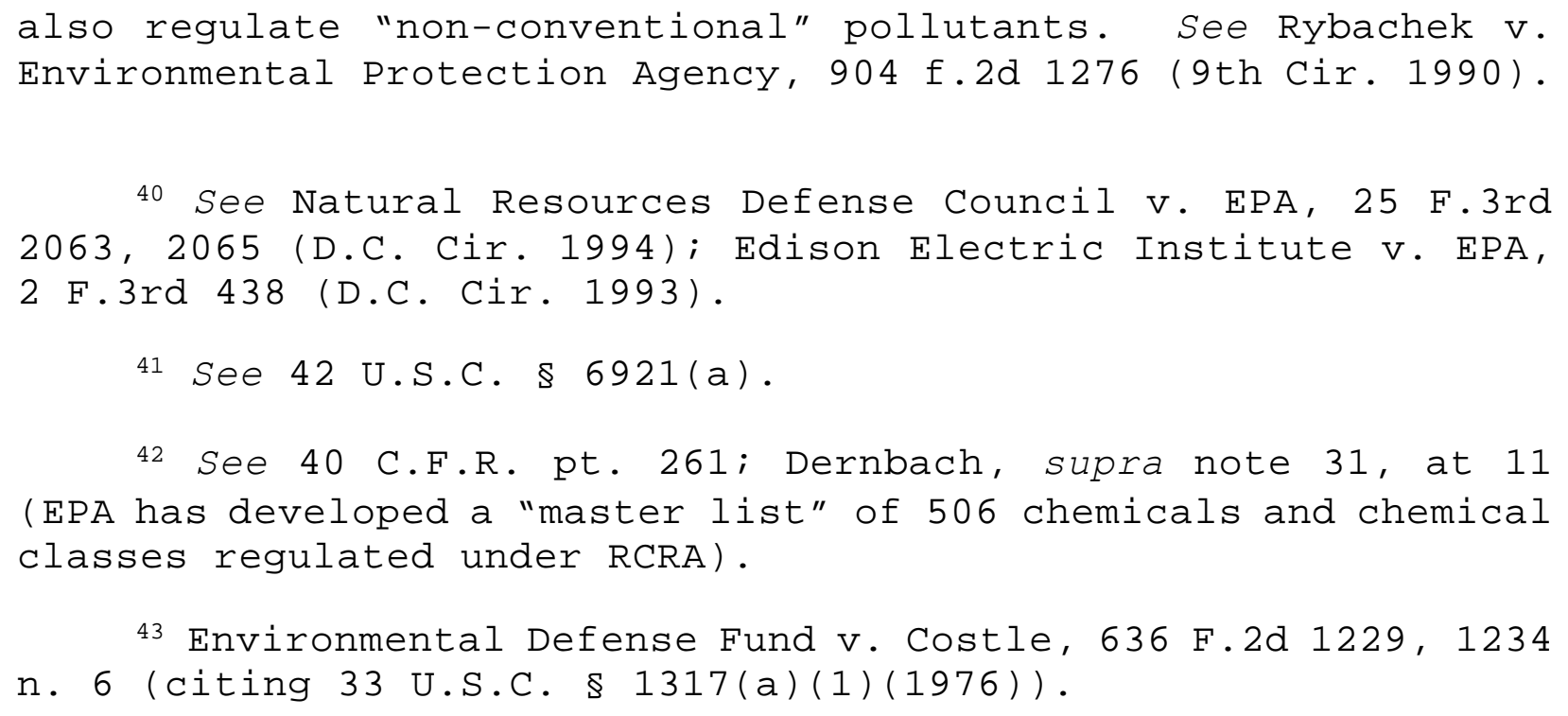


period of years not days).$^{44}$ This program was effectively paralyzed by $1978 .{ }^{45}$ Lack of data about the effects of pollutants contributed to a failure to list pollutants. ${ }^{46}$

Litigation following EPA's failure to meet its deadlines for listing and regulating toxic substances produced a consent decree that forced regulation of 65 additional "priority pollutants" and pollutant categories. ${ }^{47}$ Environmental groups agreed to more relaxed criteria for standard setting in exchange for agreement to regulate this group of priority pollutants. ${ }^{48}$ This list, however, may not have reflected agency selection of pollutants. Rather, the list may reflect a combination of government, industry, and

\footnotetext{
44 See EDF, 636 F.2d at 1234 n. 6.

45 See Oliver Houck, The Regulation of Toxic Pollutants Under the Clean Water Act, 21 Envtl. L. Rep. 10528 (Sept. 1991). 46 See Dernbach, supra note 31, at 8; Latin, supra note 16, at $1307-09$.

47 See Citizens for a Better Environment (CBE) V. Gorsuch, 718 F.2d 1117, 1120 (D.C. Cir. 1983), cert. denied, 467 U.S. 1219 (1984); Hall, The Control of Toxic Pollutants Under the Federal Water Pollution Control Act Amendments of 1972, 63 IowA L. Rev. 609 (1978); 40 C.F.R. \$ part 423 (appendix A).

48 See EDF, 636 F.2d at 1236 n. 22 .
} 
environmental group priorities, since the list came out of a consent decree. ${ }^{49}$ Congress subsequently ratified the selection of most of the pollutants in the consent decree.$^{50}$

Regulation of hazardous air pollutants has a similar history. Selection of pollutants for stringent regulation based on health effects proved extremely slow and eventually a process other than conventional agency priority setting produced a larger list. EPA regulated only 7 pollutants during the first two decades of its administration of the CAA.$^{51}$ In 1990, Congress itself listed 189 hazardous air pollutants and generally required EPA to regulate them. ${ }^{52}$

Similarly, EPA has regulated very few substances under the Toxic Substances Control Act $(\mathrm{TSCA})^{53}$ and the Federal Insecticide, Fungicide, and Rodenticide Act (FIFRA), ${ }^{54}$ which apply cost-

\footnotetext{
49 See id. at 1234-1235; Dernbach, supra note 31, at 33-34 (discussing the reasons for selection of these priority pollutants). While the industry groups involved in the initial settlement did not appeal the District Court order granting the initial settlement, see id., some industry groups later attacked it collaterally and challenged its enforcement and modification. See EDF, 636 F.2d at 1236-1238; CBE, 718 F.2d 1117 .

50 See Frank Grad, 2 Treatise on the Environment \$ 3.03[4] (1998).

51 See National Mining Ass'n v. EPA, 59 F.3rd 1351, $1364 \mathrm{n} .1$ (D.C. Cir. 1995).

52 See 42 U.S.C. \$ $7412($ b) (1). See also Dernbach, supra note

31, at 41-42 (discussing the history of the list's development).

$53 \quad 15$ U.S.C. \$\$ 2601-2692.

547 U.S.C. \$\$ $136-136 y$.
} 
benefit tests to regulatory decisions. ${ }^{55}$ The cost-benefit test stimulated strong industry resistance to providing data on health effects and led to paralyzing reversals in court, including a reversal of a ban on asbestos, one of the most well documented threats to human health in the history of environmental law. ${ }^{56}$

This history of paralysis illustrates an important point about priority setting. Agencies facing large information gaps have often been unable to complete rulemakings deciding which toxic chemicals to regulate. More than 10,000 potential toxic chemicals might require regulation. ${ }^{57}$ But EPA has never succeeded in regulating more than a handful of substances, under TSCA and FIFRA's cost-benefit requirements. ${ }^{58}$

\footnotetext{
55 See John S. Applegate, The Perils of Unreasonable Risk: Information Regulatory Policy and Toxic Substances Control, 91 Colum. L. REV. 261, 269 (1991) [hereinafter PERILS] (FIFRA and TSCA use language that authorizes action to prevent "unreasonable" adverse effects and have legislative history calling for balancing of costs and benefits); Alan Rosenthal, George M. Gray, \& John D. Graham, Legislating Acceptable Cancer Risk from Exposure to Toxic Chemicals, 19 Ecology L. Q. 269, $304-$ 309 (1990) (referring to FIFRA and TSCA as risk-balancing statutes); Corrosion Pipe Fittings v. EPA, 947 F.2d 1201, 1217 (5th Cir. 1991) (describing statutory requirements of TSCA). 56 See Corrosion Pipe, 947 F.2d 1201; Driesen, supra note 8, at 596 .

57 See Dan Fagan \& Marianne Lavelle, Toxic Deception: How the Chemical Industry Manipulates SCIENCE, Bends the LAW, AND ENDANGers Your heAlth xvii (70,000 chemicals in commerce, including more than a billion pounds of pesticides annually).

58 See McGarity, supra note 3, at 541-549 (a cost-benefit requirement and hard look judicial review ended regulation under section 6 of the Toxic Substances Control Act); Jay Michaelson, Note, Rethinking Regulatory Reform: Toxics, Politics, and Ethics, 105 YALE L. J. 1891, 1902 (1996) ("EPA is woefully
} 
Pollution control statutes also contain provisions that allow agencies to delist substances. For example, section 112 of the CAA authorizes EPA to delist Congressionally listed hazardous substance shown to be safe. ${ }^{59}$ Similar provisions exist in other statutes. ${ }^{60}$

\section{Allocation}

Congress makes allocative decisions in the budget making process. ${ }^{61}$ Congress decides how much money to give each regulatory agency. If often dedicates funds to particular programs within agencies. ${ }^{62}$ These fairly broad decisions influence allocation of funds that can finance rulewriting,

inefficient at setting numerical limits for toxic substances" having set only 17 exposure limits in 20 years under TSCA); See Donald T. Hornstein, Lessons from Federal Pesticide Regulation on the Paradigms and Politics of Environmental Law Reform, 10 YALE J. on REg. 369, 437-438 (1993). See also Applegate, supra note 55, at 318-19 (only a handful of test rules have been promulgated under TSCA).

59 See 42 U.S.C. \$ 7412 (3) (A).

60 See e.g. Environmental Defense Fund V. Costle, 636 F.2d 1229, 1238 (D.C. Cir. 1980) (Congress gave EPA the authority to delete toxic pollutants from the list established under the Clean Water Act); U.S. V. Bethlehem Steel Corp., 829 F. Supp. 1023 (N.D. Indiana 1993), affirmed in part and vacated in part, 38 F.3rd 862 (7th Cir. 1995) (adjudicating claim that petition for delisting waste under RCRA should offer a defense to enforcement).

61 See generally Max Reynolds, The Impact of Congressional Rules on Appropriations Law, 12 J. L. \& Politics 481 (1996).

62 See National Academy of Public Administration (NAPA), Setting Priorities, Getting Results at 150 (1995) (describing how "earmarking" by Congress limits EPA's ability to allocate money based on risk) 
adjudication, and enforcement among the various regulatory agencies and their programs. Congress controls the allocation of funds between different regulatory programs with different goals. ${ }^{63}$

Some of these allocation decisions really function as selection decisions, a type of secondary priority setting. Congress, especially in recent years, has sometimes passed appropriations riders (prohibitions on expenditures for particular purposes attached to long budget bills) to forbid the expenditure of monies for specified purposes. ${ }^{64}$ For example, recent Congresses have passed appropriations riders forbidding expenditures aimed at addressing global climate change, a problem EPA and its Scientific Advisory Board ranks high among its list of priorities. ${ }^{65}$ But aside from appropriations riders, Congress usually allocates funds to various programs with the apparent goal of making sure that the agencies execute the programmatic instructions in substantive legislation. ${ }^{66}$ Agencies generally have to make decisions about how much time and money to devote to various regulatory tasks within the formidable constraints Congress imposes. Thus agency managers

\footnotetext{
63 See generally Kate Stith, Congress' Power of the Purse, 97 YaLE L. J. 1343 (1988).

64 See Sanda Beth Zellmer, Sacrificing Legislative Integrity at the Altar of Appropriations Riders: A Constitutional Crises, 21 HARV. ENVT' L L. REV. 457 (1997).

65 See EPA, Unfinished Business: A Comparative Assessment of Environmental Problems 97 (1987); Environmental Protection Agency Science ADVISORY BOARD, REDUCING Risk: SETting PRIORIties AND Strategies for ENVIRONMENTAL PROTECTION 3 (1990) [hereinafter, SAB StUdy].

66 Adam M. Finkel, Should We-and Can We-Reduce the Worst Things First?, in Worst Things First? The Debate Over Risk-Based NAtional Environmental Priorities at 5 (Adam M. Finkel \& Dominic Golding eds. 1994) (95\% of EPA's budget subject to Congressional mandates).
} 
must decide how many people to assign to several rulemaking projects going on at the same time and how much money to devote to financing contractors to provide additional information within the constraints Congressional earmarking imposes. ${ }^{67}$

Congress through substantive legislation determines the criteria that apply to determining the stringency of various types of regulation. Agencies implementing pollution control statutes translate these general instructions into specific decisions about the stringency of each regulation it promulgates, unless Congress itself has made very specific decisions. ${ }^{68}$ These decisions may affect the amount of money regulated companies pay to comply with regulatory requirements. This in turn effects allocation of company resources, both employee time and money. It forces managers to divert resources that it may have devoted to advertising, product improvement, developing new products, and enriching managers or shareholders to pay employees or contractors to make environmental improvements. Managers must, in short, give environmental protection a greater priority than they would have without the standard. Stringent standards will usually (but not always) divert more private sector monies to compliance than less stringent standards.

\section{Priority Setting in the Regulatory Reform Debate}

Claims that society sets its regulatory priorities badly have become a staple of the regulatory reform debate. This part surveys some of the more prominent claims and shows that critics of government priority setting have been less than clear about what they mean by setting priorities. It then

\footnotetext{
67 See NAPA, supra note 62, at 158-62 (describing how EPA deploys staff informally to try and target high risk).

68 See e.g. David M. Driesen, Five Lessons from the Clean Air ACt's Implementation, 14 PACE ENVT'L L. Rev. 51, 52-55 (1996).
} 
contrasts the evidence of poor priority setting that the critics put forward with the evidence an adequate conceptual framework and knowledge of the law of priority setting might lead one to expect.

Regulatory reformers have provided very little information relevant to assessing the claim that regulatory priorities are seriously askew.

\section{A. Stephen Breyer's Breaking the Vicious Circle}

Harvard law professor Stephen Breyer wrote a very influential book on regulatory reform prior to becoming a Supreme Court Justice, Breaking the Vicious Circle: Toward More Effective Risk Regulation. ${ }^{69}$ This book advocates a shift in how we set priorities, insulation of regulators from Congressional control of agency agendas. ${ }^{70}$

For my purposes, Justice Breyer's diagnosis of priority setting problems is of more interest than his reform proposal. Justice Breyer identifies three "major" problems with the current regulatory system, which he labels "tunnel vision (or "the last 10 percent"), random agency selection, and inconsistency. ${ }^{71}$

He defines "tunnel vision" as carrying "single-minded pursuit of a single goal too far, to the point where it does more harm than good." ${ }^{, 72}$ He then provides examples of what he considers overly

\footnotetext{
69 Breyer, supra note 1.

70 See Lisa Heinzerling, Political Science, 62 U. CHI. L. REv. 449, 461 (1995) (book review) ("Breyer's book is, perhaps most of all, a call for better prioritization.")

71 BREYer, supra note 1 , at 10.

72 Id. at 11 .
} 
stringent regulation and suggests that such excess is pervasive. ${ }^{73}$ In each case, Justice Breyer uses a dollars per lives saved metric to evaluate whether regulation is too stringent. In other words, he reaches his conclusion that tunnel vision is an important problem through application of CBA, and a rather crude and incomplete version of CBA at that. His analysis does not consider avoided sickness and harms to ecosystems as a benefit of regulation, only avoided human deaths. ${ }^{74}$ Because of this some of Justice Breyer's critics accuse him of a kind of tunnel vision of his own. ${ }^{75}$

He does not, however, argue explicitly for either CBA or allocative efficiency. He simply assumes that outcomes that differ from those dictated by a crude version of that methodology are bad. His conclusion about the significance of this "tunnel vision," defined as regulations having high marginal cost per life saved, addresses priority setting. He argues that the tunnel vision argument supports "a serious effort to prioritize, and perhaps to reallocate, our regulatory resources." ${ }^{, 76}$ He does not explain what he means by prioritizing, reallocation, or regulatory resources.

Justice Breyer then turns his attention to "random agenda selection.",77 This reference to agenda setting seems to address the kind of priority setting that I have identified as "selection," deciding to

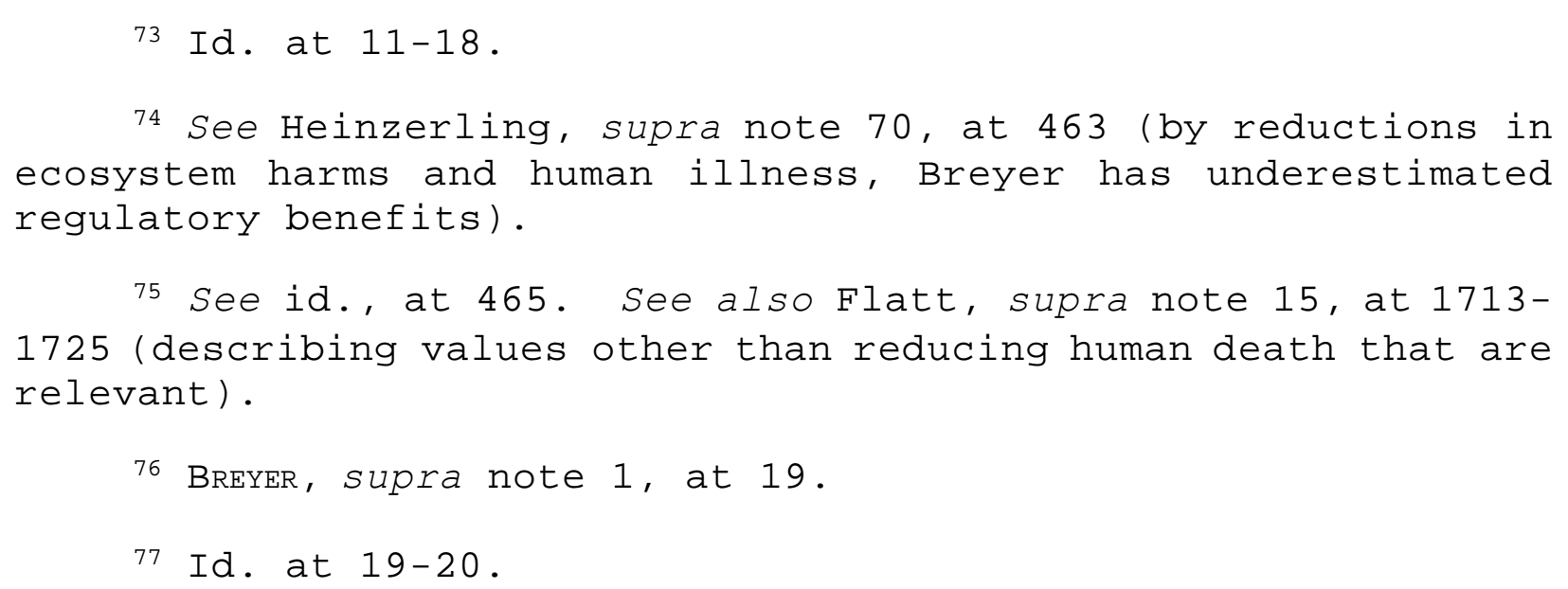


perform some tasks and not others. Indeed, he begins by discussing the problem of EPA regulating only a small fraction of the 60,000 toxic chemicals then on the market, suggesting a need for more careful selection. $^{78}$

But this conceptual clarity soon evaporates, as Justice Breyer contrasts EPA's views about which environmental problems merit high priority treatment with those of the public. ${ }^{79}$ At this point, Breyer apparently recognizes that EPA has not suggested that its low or medium priorities should be left off its agenda, ${ }^{80}$ and he writes about agency "priorities and agendas" mirroring public rather than expert judgment. ${ }^{81}$ Apparently, this dual reference flags some sort of priority setting in addition to agenda setting, something more than selection. To make matters worse, he closes this discussion of agenda selection with a reference to one of his examples of overly stringent regulation. ${ }^{82}$ At this point, the reader cannot tell whether his agenda setting discussion focuses upon priority setting, or the need to reduce the stringency of regulation hinted at earlier. I will discuss the relationship between the stringency of regulation and priority setting in part four. Understanding this relationship helps clarify an important confusion in the regulatory reform debate.

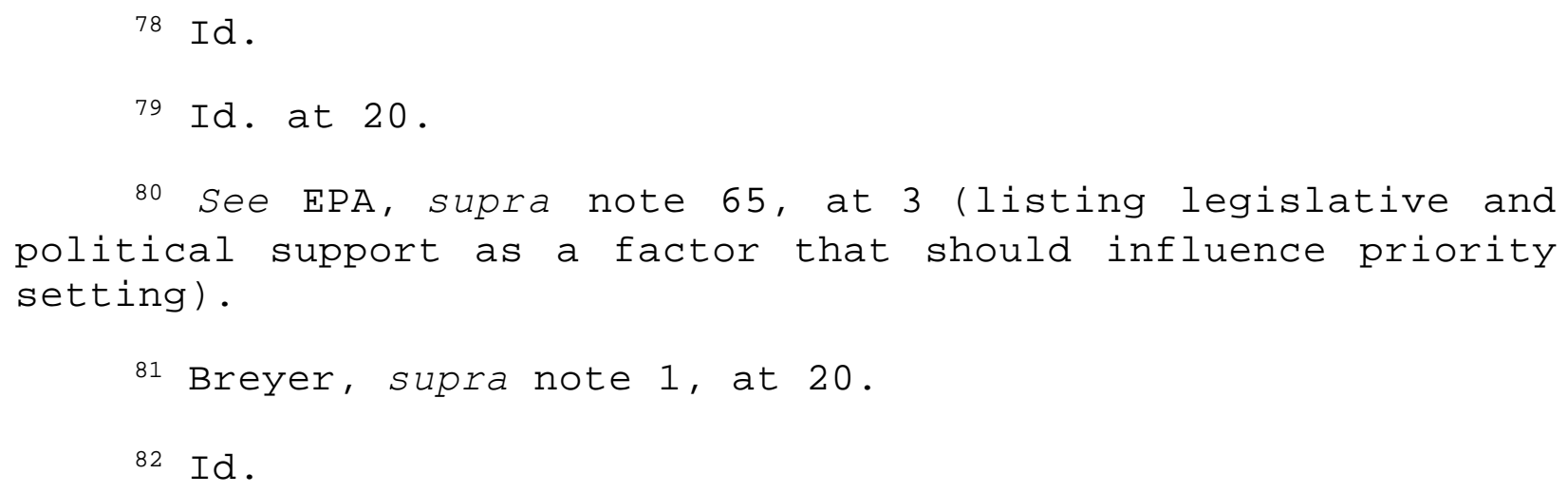


Finally, Justice Breyer turns his attention to the problem of "inconsistency." Under this rubric, Breyer briefly addresses a host of potential problems. He first discusses the use of different risk estimation methods among agencies. ${ }^{83}$ He states that "regulators implicitly attach" widely varying values to statistical lives saved. ${ }^{84}$ He then turns his attention to problems that seem to have nothing to do with consistency. He discusses regulators' failure to attend to “one program's safety or environmental effects upon another" and other unintended consequences. ${ }^{85}$ Still under the rubric of consistency, he returns to his cost-benefit and allocation themes. He suggests that spending too much on "small risks", a failure to observe cost-benefit principles, is not only uneconomic, but often fatal. ${ }^{86}$ He talks about how imposing costs for environmental cleanup deprives individuals of income. This deprivation can lead to poor diet, more heart attacks, and suicide, says Breyer. ${ }^{87}$

He returns to his priority setting theme, in a manner suggestive of concern about allocative priority setting, by claiming that concrete possibilities exist for obtaining "increased health, safety, and environmental benefits through reallocation of regulatory resources." ${ }^{" 88}$ Here he gives some examples of good ways to spend money, but does not specify which resources he proposes to use for this purpose. Part four will return to this problem.

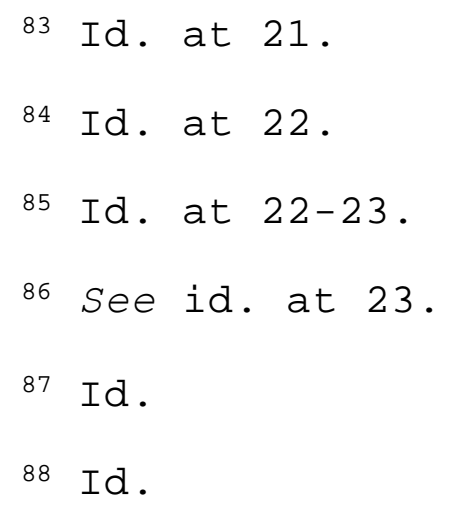


In short, Breyer's concept of priority setting is extremely unclear. He tends to treat overly

stringent regulation as a form of poor prioritizing, but does not explain what stringency has to do with

priority setting.

Some commentators criticize Breyer's description of regulation, stating that he provides a

skewed picture of government regulation. ${ }^{89}$ Many more disagree with his recommendation to solve the

problems of tunnel vision, random agenda selection, and inconsistency, protecting a bureaucracy from

the influence of public opinion, so that expert opinion can independently create environmental policy. ${ }^{90}$

89 See e.g. Heinzerling, supra note 70; David A. Wirth \& Ellen K. Silbergeld, Risky Reform, 95 Colum. L. Rev. 1857, 1880 (1995) (book review) (Breyer recites a "highly selective, onesided litany of supposedly absurd regulatory requirements."); Flatt, supra note 15, at 1712 (faulting Breyer for failing to distinguish between "isolated examples" and "structural deficiencies"); Oliver Houck, Risk Management Gone too Far, ENv'T FORUM 8 (March/April 1994) (case histories focus on examples of regulation going too far rather than the many cases where it did not go far enough).

90 See e.g. Pildes \& Sunstein, supra note 1, at 86-89; David A. Dana, Setting Environmental Priorities: The Promise of a Bureaucratic Solution, 74 B.U.L. Rev. 365, 379-381 (1994) (book review); Wirth \& Silbergeld, supra note 89, at 1889-1893; Houck, supra note 89, at 9 (explaining why he finds Breyer's proposal "disturbing"); Todd C. Zuble, Breaking the Vicious Circle: Toward Effective Risk Regulation, 8 HARV. J. L. \& TECH. 241, 247 (1994) (book note) (criticizing Breyer's failure to limit his proposed bureaucracy's power). Cf. Barry Sullivan, Democracy, Bureaucracy, and Science: Making the Trains Run on Time, 89 Nw. U. L. REv. 166, 176-190 (1994) (book review) (gently critiquing Breyer's proposal); Craig Gannett, Congress and the Reform of Risk Regulation, 107 HARV. L. Rev. 2095, 2100 (1994) (suggesting a need for greater clarity about the limits of Breyer's agency's political authority); Stephen F. Williams, Risk Regulation and Its Hazards, 93 MIch. L. Rev. 1498 (1995) (expressing doubts about the political acceptability of Breyer's remedy). 
None of these criticisms go to the heart of the problem of interest here, what sort of priority setting does Breyer address? This matters, because Breyer's views about the current state of the regulatory system have proven influential, even if his recommendation for reform has not. Indeed, while Breyer himself did not recommend increased reliance upon CBA in this book, both supporters of regulatory reform in the Congress and prominent academics have used his view of regulation to support increased use of CBA as a means of improving priority setting. ${ }^{91}$

\section{B. Sunstein's Endorsement of Cost-Benefit Analysis to Improve Priority Setting}

Cass Sunstein identifies the need for better priority setting as the first lesson we all have learned from regulation since the New Deal. ${ }^{92}$ Citing Breyer, Sunstein claims that "resources for risk reduction are badly allocated."93 Better allocation, Sunstein claims, would save either more lives or allow us to save the same number of lives at lower cost. ${ }^{94}$ Like Breyer, he does not discuss which resources he proposes to reallocate or how. But initially, he seems to be discussing some form of secondary allocative priority setting, perhaps selection.

\footnotetext{
91 See Republican National Committee, Contract with America 131-132 (Ed Gillespie \& Bob Schellhas eds., 1994)(faulting Congress for failing to assure the regulation's benefits outweigh costs, for not pursuing "integrated health and safety goals" and for attacking whatever health risk has caught the public's attention, even if it exacerbates other health risks.); Pildes \& Sunstein, supra note 1, at 4; Sunstein, Foreword, supra note 1, at 257-260; Sunstein, Cognition, supra note 1 .

92 Sunstein, Foreword, supra note 1, at 257-260.

93 Id. at 257.

94 Id. at 262 .
} 
He then goes on to a problem with no obvious connection to priority setting, regulations that he claims offer too few benefits to justify their costs. ${ }^{95}$ Like Breyer, he criticizes the unevenness in the amount of private compliance cost dollars spent per lives saved across regulatory programs. ${ }^{96}$ He then discusses, as Breyer did, inconsistency in agency risk assessment procedures. ${ }^{97}$

Throughout this discussion he refers to the "goal of achieving sensible priority setting." finds "good priority setting" unlikely because of the inconsistencies he has cited.99

He does not explain how inconsistencies in risk assessment and regulatory stringency affect priority setting. He does not clarify what he means by priority setting and why these inconsistencies undermine good priority setting. He assumes some relationship between even dollars per life saved results, standardized risk assessment, and good priority setting. But he does not explain why these things are related.

Sunstein makes a number of recommendations for regulatory reform. ${ }^{100}$ Since my aim here is simply to set our prioritizing talk straight, I plan to focus on Sunstein's principle recommendation for

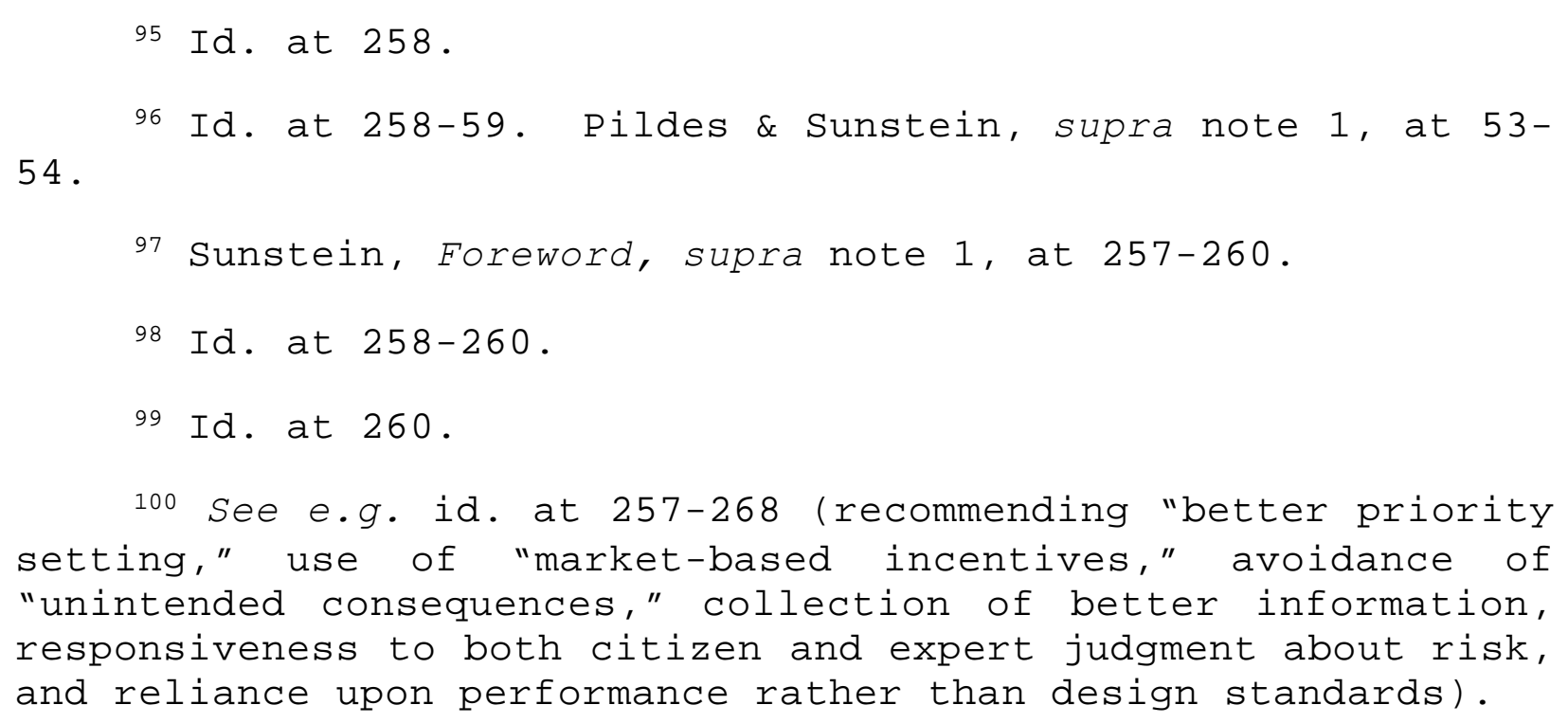


improving priority setting, increased use of CBA. Sunstein generally endorses CBA, in large part, because he believes it encourages better priority setting. ${ }^{101}$

\section{Evidence of Poor Priority Setting in the Regulatory Reform Debate}

The evidence of poor priority setting that Breyer, Sunstein, and other regulatory reformers put forward differs markedly from what any common sense concept of government priority setting and knowledge of the law governing it would lead one to expect. Spelling out the kind of inquiry a common sense concept of priority setting invites will help make this apparent.

The regulatory reformers, including Sunstein and Breyer, show no concern about ordering. But many people may think of ordering first when they think about setting their priorities straight. Some people even establish priorities by writing lists of important tasks in a rank order.

This lack of concern for ordering means that the regulatory reform debate's priority setting rhetoric appears misleading. After all, ordering involves perhaps the most neutral form of priority setting. Ordering government priorities does not, for example, involve expansion or contraction of regulatory programs or implicate the stringency of regulation. The regulatory reformer's use of the priority setting theme conveys the relative neutrality that criticism of ordering implies, but the details of the criticism do not address ordering.

The regulatory reformers do not discuss rulemaking or statutes that establish an order of operations. We have no idea whether regulatory reformers consider the ranking of superfund sites, the

\footnotetext{
101 See Sunstein, Cognition, supra note 1, at 2 (CBA is a way of "ensuring better priority-setting and of overcoming predictable obstacles to desirable regulation"); Pildes \& Sunstein, supra note 1 , at 52 .
} 
order EPA and Congress have established for regulating hazardous air pollution sources, or the decision to regulate large point sources of water pollution first reflects poor priority setting.

Knowledgeable discussion of such matters would carefully consider the criteria Congress imposes upon EPA to establish an order and EPA's execution of this ordering. It would come to grips with the issues these criteria and EPA's execution raise in a concrete way. And reform recommendations would flow from the evaluation of this experience. None of this figures at all in the work of the principal writers about priority improving regulatory reform.

Similarly, selection does not seem central to their concerns. The law of selection shows that an analyst wishing to think concretely about priority setting as selection has some data sets to work from. EPA has selected a handful of pollutants for intensive state regulation under the Clean Air Act. ${ }^{102}$ The regulatory reformers express no views about whether these "criteria" pollutants merit this special attention. If they do not think that lead, ${ }^{103}$ ozone, ${ }^{104}$ carbon monoxide, ${ }^{105}$ sulfur oxides, ${ }^{106}$ particulate matter, ${ }^{107}$ and nitrogen oxides ${ }^{108}$ merit this attention, perhaps they should explain why not. On the other hand, if EPA chose these pollutants wisely, perhaps government selective priority setting has been

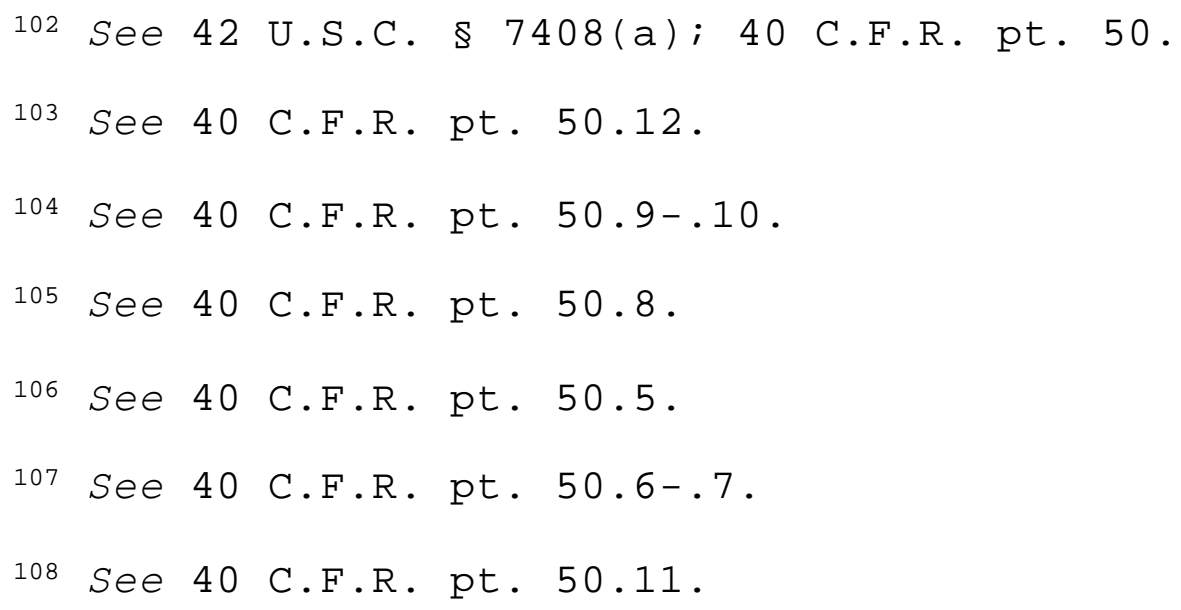


pretty good. Regulatory reformers have equally little to say about the selection of priority pollutants under the Clean Water Act, ${ }^{109}$ the list of hazardous air pollutants regulated under the CAA, ${ }^{110}$ or any similar exercise in selection. If a serious selection problem exists, one would expect these lists to show many glaring mistakes. ${ }^{111}$

Breyer and Sunstein have very little to say about selection. Sunstein addresses selection in a brief and very puzzling passage. He claims that agencies have substantially different standards for deciding whether to regulate at all. ${ }^{112} \mathrm{He}$ then cites varying probabilities of cancer risk that serve, he says, as regulatory triggers at various agencies. ${ }^{113}$ But Sunstein does not make a normative case for setting a single numerical estimate of cancer risk as the criterion for initiating regulation. Indeed, he states that "a single number may not make sense in light of different contextual judgments."114 Given that statement, his conclusion that "good priority setting is unlikely" in the face of these variations seems

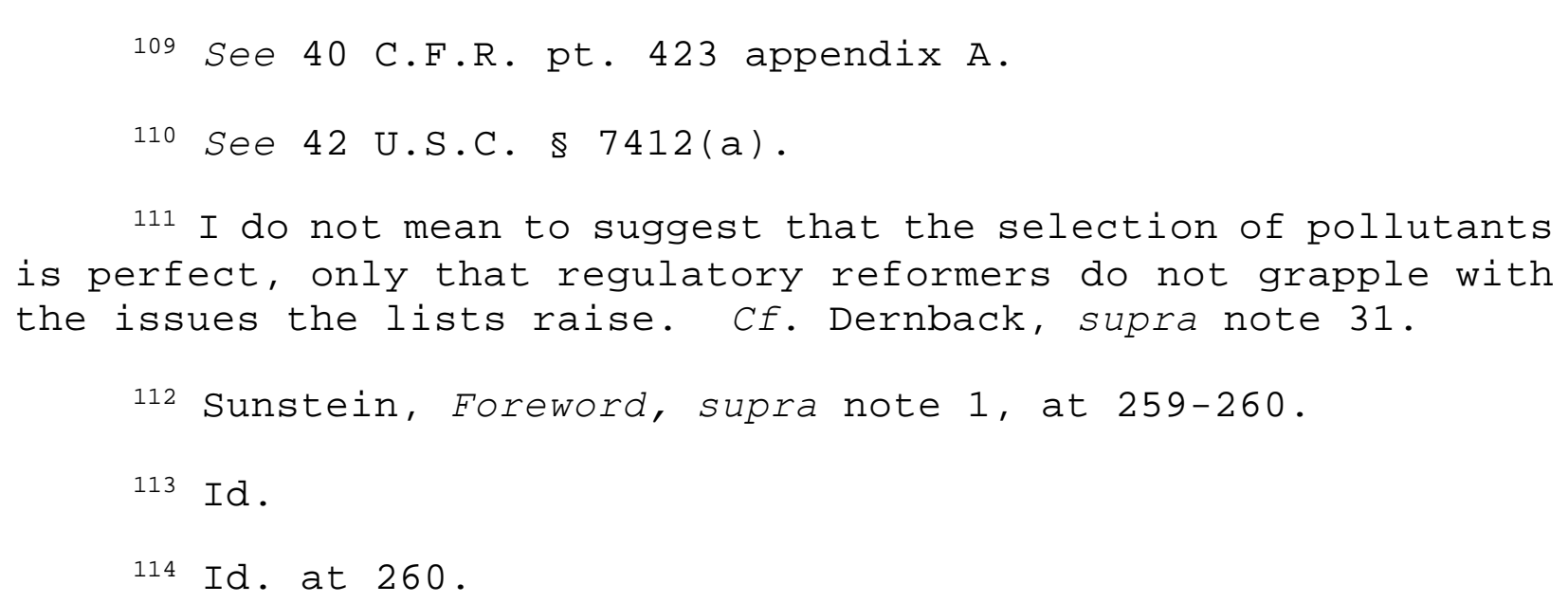


baffling. ${ }^{115}$ To the extent agencies are making judgments based on numerous contextual factors, one would expect variations, even substantial variations, in any single metric. ${ }^{116}$

Breyer's book briefly mentions the problem of EPA not securing enough information about toxic chemicals under TSCA. ${ }^{117}$ This makes it difficult for EPA to carefully select chemicals for regulation.

Breyer then mentions complaints that EPA overemphasizes cancer rather than neurological risk. ${ }^{118}$ He recognizes that "some neurotoxins are regulated as carcinogens," but "neurotoxic effects receive little special attention." 119 This reference to "special attention" raises the possibility that this

115 Id. at 260 . that EPA "attach as much importance to reducing ecological risk as it does to reducing health risk").

117 Breyer, supra note 1, at 19-20. See also Applegate, supra note 55, at 318-30 (explaining how TSCA's unreasonable risk standard for requiring testing has tended to discourage information gathering and recommending reforms).

118 Id. at 20. Cf. Lead Industries V. EPA, 647 F.2d 1130 (D.C. Cir. 1980), cert. denied, 449 U.S. 1042 (upholding EPA listing of the neurotoxin, lead, as a criteria pollutant); Ethyl Corp. V. EPA, 541 F.2d 1 (D.C. Cir. 1976) (en banc), cert. denied, 426 U.S. 941 (upholding EPA's phasedown of lead in gasoline); Acorn v. Edwards, 81 F.3rd 1387, 1388-89 (5th Cir. 1996), cert. denied, 521 U.S. 1129 (1997) (discussing the Lead Contamination Control Act of 1988); Adamo Wrecking V. EPA, 434 U.S. 275, 297 n.9 (1977) (dissent) (mentioning that mercury, a neurotoxin, has been regulated as a toxic pollutant under the Clean Air Act); Friends of the Earth v. Laidlaw, 120 S.Ct. 693, 701-702(2000) (referring to Clean Water Act standards for mercury).

119 Breyer, supra note 1, at 20 [emphasis added]. 
complaint about lack of "special attention" might refer to a problem of inadequate stringency of regulations addressing neurotoxic carcinogens or inadequate information gathering, rather than a problem of selection of substances for government regulation. ${ }^{120}$

Regulatory reformers devote scant attention to selection and none at all to ordering. Their chief concerns lie far from the common sense notion of priority setting as either ordering or selection.

Both Sunstein and Breyer place major emphasis on improving the allocation of resources, thus suggesting a concern with allocative priority setting. ${ }^{129}$ Yet, they say nothing concrete about Congressional budgetary processes that govern allocation of most money among competing regulatory programs or about management decisions assigning agency personnel and contractor dollars to competing regulations within programs.

Breyer, Sunstein, and other regulatory reformers focus upon claims that EPA's expert views about the relative seriousness of various environmental problems do not match those of the general

\footnotetext{
120 Cf. Thomas O. MCGarity, OSHA's Critics and Regulatory Reform, 31 WAKE FOREST L. REv. 587, 646 n. 200 (1996) (discussing lack of available risk assessment techniques for neurotoxicity); Wirth \& Silbergeld, supra note 89, at 1865 (claiming that cancer tends to take precedence over other risks because risk assessment methods are available to estimate low dose cancer risks); Wendy E. Wagner, Congress, Science, and Environmental Policy, 1999 U. Ill. L. Rev. 181, 286 n. 57 (as of 1997, scientists had not developed low cost screening tests for neurotoxicity); 64 Fed. Reg. 42945 (Aug. 6, 1999) (requiring neurotoxic testing for a limited group of pesticides); EPA, Principles of Neurotoxicity Risk Assessment, 59 Fed. Reg. 42360 (Aug. 17, 1994).

129 See Breyer, supra note 1, at 19 (discussing possible need to reallocate "regulatory resources"); Sunstein, Foreword, supra note 1, at 257-258 (developing point that "resources for risk reduction" are badly allocated).
} 
public. Breyer and Sunstein tell us that EPA has indicated that the priorities it considers most important did not match its actual allocation of resources. ${ }^{130}$ This suggests some concern with allocation of government resources.

Let us assume that EPA experts are correct, that their views do not track the public's incorrect view, and that allocation of government resources is not proportional to the relative importance of competing environmental programs. The conceptual framework in part one invites further questions that the regulatory reformers do not ask. First of all, does this lack of correspondence between funding and importance involve any priority setting at all? Suppose that some tasks are more difficult to accomplish than others. If this is the case, than a government committed to an appropriate set of tasks might allocate resource unevenly based on the relative difficulty of competing tasks rather than their relative importance.

Justice Breyer states that a major concern involves the failure of Congress to fund pursuit of EPA's highest priorities (such as indoor air pollution and climate change), while it continues to fund hazardous waste clean-up, a low EPA priority, rather well. ${ }^{131}$ This, of course, suggests not poor

\footnotetext{
130 See BREYER, supra note 1 , at 20; Pildes \& Sunstein, supra note 1 , at 36-37; Frederick Allen, environmental protection Agency. Cf. EPA, supra note 65, at xvii (EPA made no decisions that one type of risk was more important than another and did not add risks for a problem across different types of risk).

131 See EPA, supra note 65, at xvii (citing the need for effective application of EPA's own finite resources as the reason for the Unfinished Business analysis) [emphasis added]; F. Henry Habicht, EPA's Vision for Setting National Priorities, in Worst Things First?, supra note 66, at 50-51; Breyer, supra note 1, at 20 .
} 
agency priority setting, but poor Congressional allocation of funds. ${ }^{132}$ Yet, Sunstein and many other regulatory reformers devote little attention to budgetary issues, focusing their recommendations on changes in administrative agency decision-making procedures. ${ }^{133}$

This lack of focus on budget causes most regulatory reformers to fail to address issues crucial to the budgetary concerns underlying the EPA report on priority setting that they both refer to in discussing these problems. ${ }^{134}$ Government has funded superfund (a low EPA priority) through a dedicated tax on the industries manufacturing the chemicals piled up in toxic waste dumps. ${ }^{135}$ This may

\footnotetext{
132 See SAB Study, supra note 65, at 3 (explaining that Congress largely determines agency priorities and budget). This report focused its recommendations upon EPA, probably because EPA, not Congress, asked for guidance. Id. at ii, 6. See also Frederick W. Allen, Differing Views of Risk: The Challenge For Decision-Making in a Democracy, presented at Only Earth Forum on Managing Hazardous Materials at The Rene Dubois Center for Human Environments, Inc., New York City, 17-18 (May 25-26, 1988)(framing the major issue as legislative and budget priorities tracking public rather than expert opinion); NAPA, supra note 62, at 153 (specific directions from congress accounts for nearly all of the agent's budgetary priorities, thus precluding agency reliance upon risk assessment to set budgetary priorities).

133 Cf. NAPA, supra note 62, at 147-158 (describing the budget process).

134 See EPA, supra note 65, at xix (discussing lack of correspondence between EPA's assessment of risk and EPA "effort"); Hornstein, supra note 54, at 377-388 (discussing EPA's integration of risk-based priorities into budget processes); Donald Hornstein, Reclaiming Environmental Law: A Normative Critique of Comparative Risk Analysis, 92 Colum. L. Rev. 562, 564 (1992) (citing Office of Management and Budget efforts to use comparative risk analysis to determine the flow of money to federal programs).

$$
135 \text { See } 42 \text { U.S.C. \$ 9611; } 26 \text { U.S.C. \$ 9607(b)(1). }
$$
}


help explain the relatively healthy state of EPA's superfund budget. Yet Sunstein and most other

regulatory reformers do not discuss abolishing the superfund tax or taxing something else to fund

different priorities. ${ }^{136}$ Thus, they do not grapple with the issue of whether it really makes sense to leave

toxic waste dumps lying around without cleanup, or the implications of milder reforms aimed at the

budgetary problem. ${ }^{137}$

136 Cf. Katherine D. Walker, March Sadowitz, and John D. Graham, Confronting Superfund Mythology: The Case of Risk Assessment and Management, in Analyzing Superfund 30-32 (Richard L. Revesz and Richard B. Stewart eds. 1995) [hereinafter SupERfund] (both cancer and non-cancer risk at superfund sites justify remedial action).

137 Breyer does suggest that the expert government agency he proposes might obtain funds for vaccinations by looking for "practical ways to settle some toxic waste dump cases." See Breyer, supra note 70, at 67. This proposal suffers from the same problem that afflicts many other regulatory reform arguments, it does not explain whether private sector or public sector resources would fund the vaccinations. Breyer may have in mind that the settlements would impose less stringent cleanup obligations upon regulated parties and that this would free up additional resources to fund vaccinations. But less stringent clean-up obligations would allow private parties to simply keep their money, and would not directly create funding for childhood vaccinations. Perhaps Breyer means that government would save enforcement resources through settlement and that his expert agency should have authority to use those saved resources to fund a non-environmental risk reduction program. Breyer offers an alternative solution that does not suffer from this pubic/private confusion, taxing toxic chemicals to fund childhood vaccination. Id. But, as Professor Heinzerling points out, this suggestion seems inconsistent with Breyer's view that the risks from toxic substances have been exaggerated. See Heinzerling, supra note 70, at 469. It also raises issues about the limits of the appropriate authority for his proposed group and fairness to the chemical manufacturers. See National Cable Television Ass'n V. United States, 415 U.S. 336, 341 (1973) (questioning legitimacy of delegating taxation authority to a regulatory agency) . 
They also do not discuss the causes of the high costs of Superfund cleanup. First and foremost, unlike many regulatory programs, this program focuses upon cleaning up pollution after it goes into the environment. ${ }^{138}$ Cleanup often costs more than pollution prevention. A related problem complicates Superfund cleanup. Since the dumping that occurred took place in the past, figuring out who should pay for clean-up is far more complicated than figuring out who should be responsible for ongoing pollution. ${ }^{139}$ Also, because each Superfund site offers, at least initially, a black box containing a unique problem, figuring out what to do is inherently inefficient. ${ }^{140}$ EPA must proceed through case by case investigations, administrative decisions, negotiations, and adjudication. ${ }^{141}$ For many other problems,

\footnotetext{
138 See e.g. United States v. Occidental Petroleum, 200 F.3rd 143, 146 (3rd Cir. 1999) (describing remediation of already contanimated sites as CERCLA's most important essential purpose).

139 See Lloyd S. Dixon, The Transaction "Costs Generated by Superfund's Liability Approach, in SuPERFund, supra note 136, at 172-74, 176 (discussing how the existence of multiple potentially liable parties generates high transaction costs). See e.g. Sun Company Inc. v. Brown-Ferris, 124 F.3rd 1187, 1193 (10th Cir. 1997) (discussing problem of "orphan shares," clean-up costs left over because some contributors to a toxic waste spite have vanished or become insolvent).

140 See e.g. National Association of Manufacturers v. Dep't of Interior, 134 F.3rd 1095 (D.C. Cir. 1998) (rejecting challenge to methods for assessment of damages to natural resources); Kenecott Copper Corp. v. Department of Interior, 88 F.3rd 1191, 1219 (D.C. Cir. 1996) (discussing need to have site assessment methods sufficiently flexible to address "the unique circumstances of each case.")

141 See Richard B. Stewart, Confidentiality in Government Enforcement Proceedings, 2 N.Y.U. EnVtL. L. J. 232, 235-36 (1993) (describing the case-by-case process); Kelley V. EPA, 15 F.3rd 1100, 1104-1109 (D.C. Cir. 1994), cert. denied sub nom. American Banker's Association V. Kelley, 513 U.S. 1110
} 
EPA can use the much more efficient method of broad industry-wide rulemaking to address

problems. ${ }^{142}$ This means, of course, that the disproportionate funding may reflect a difficulty allocation, rather than priority setting.

Commentators that appreciate these problems tend to come to different conclusions than the scholars who have led the mainstream debate on regulatory reform. For example, a coalition of environmental groups and regulated companies agreed that more definite prospective standard setting would help speed up clean-up. ${ }^{143}$ Unfortunately, Congress did not enact this reform proposal. ${ }^{144}$ I do not mean to suggest that Superfund would not benefit from regulatory reform. I just mean that the regulatory reformers' discussion of priority setting in this context suffers from a lack of serious interest in the actual allocation of government resources.

Justice Breyer, after making the briefest mention of EPA's concern about budgetary allocation, refers the reader to a superfund clean-up with very high costs relative to benefits. This stringency concern really lies at the heart of the regulatory reformers' concerns. Breyer and Sunstein both suggest

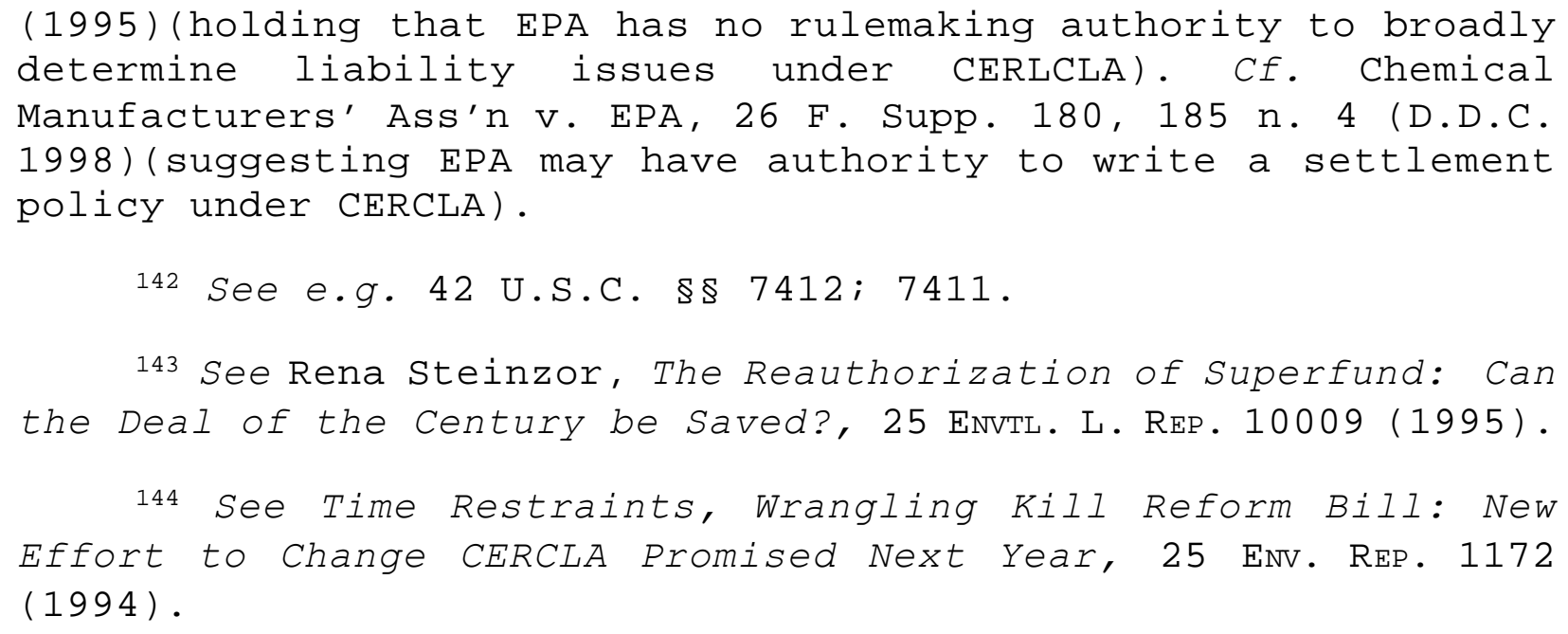


that government regulates many problems too stringently and a few not stringently enough. ${ }^{145}$ Sunstein clearly equates regulations generating costs exceeding benefits with poor priority setting. ${ }^{146}$

Regulatory reformers do not discuss stringency in any systematic manner either. Certain kinds of information seem quite germane to debates about relative stringency. For example, while EPA has regulated many chemicals, it has banned very few. One might examine whether the bans (e.g. DDT, ${ }^{147}$ ozone depleting chemicals, ${ }^{148}$ lead in gasoline ${ }^{149}$ ) have applied to important or trivial risks and how they affected society.

One might also get at policy decisions about stringency by comparing statutory criteria. For example, the Clean Air and Water Acts have rather absolute health and environmental goals, while

\footnotetext{
145 See Pildes \& Sunstein, supra note 1, at 99; Breyer, supra note 1 , at $11-29,56$.

146 See Sunstein, Legislative Foreword, supra note 1, at 257 n. 35 and accompanying text (citing statements about costs exceeding benefits to support claim that "resources for risk reduction are badly allocated" under a heading stating that "Government should engage in better priority setting").

147 Environmental Defense Fund V. EPA, 489 F.2d 1247 (D.C. Cir. 1973) (affirming ban of DDT).

148 See 42 U.S.C. \$ $7671 \mathrm{c}-\mathrm{e}$.

14942 U.S.C. \$ $7545(n)$.
} 
TSCA authorizes cost-benefit balancing. ${ }^{150}$ One might ask whether a substantial reason exists to regulate less strictly under TSCA than we do under the air and water acts. ${ }^{151}$

Basically, the regulatory reformers rely upon anecdote to suggest that environmental law is too strict. Indeed, Breyer admits that his examples of regulatory problems are "selective" and "focus on

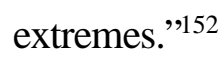

Most CBA supporters rely heavily upon a table listing dollars per lives saved numbers for regulations to justify their support of greater reliance upon CBA in regulatory proceedings. ${ }^{153}$ This table covers only a small smattering of regulations that the table's author, Office of Management and Budget economist John Morrall, has selected. ${ }^{154}$ Professor Heinzerling has shown that the Morrall table

150 Compare Corrosion Pipe Fittings V. EPA, 947 F.2d 1201, 1217 (5th Cir. 1991) (requiring a cost-benefit approach to TSCA, while adjudicating a rulemaking addressing many asbestos sources)) with Lead Industries V. EPA, 647 F.2d 1130 (D.C. Cir. 1980) (forbidding consideration of cost in setting national ambient air quality standards under the clean Air Act, while recognizing that state pollution control standards to meet this goal may involve cost considerations); Environmental protection Agency v. National Crushed Stone.

151 See Driesen, supra note 8, at 562-563 (suggesting that the difference in statutory criteria may serve the aim of equity toward polluting industries, since the air and water acts focus upon pollution control while TSCA and FIFRA contemplate product bans).

152 See Breyer, supra note 1 , at 28.

153 Lisa Heinzerling, Regulatory Costs of Mythic Proportions, 107 YALE L. J. 1981, 1983, 1993-98 (1998) (describing the influence of Morrall's table).

154 See id. at 1999-2017. 
contains major errors. ${ }^{155}$ Morrall includes rules that were never promulgated as examples of extreme regulation and often uses his own estimates of the value of regulatory benefits, even though Breyer cites this table as a compendium of information based upon EPA's own valuation of regulatory benefits. ${ }^{156}$

This reliance upon selective anecdotal information makes the reformers' claims about the state of regulation and appropriate directions for reform suspect. ${ }^{157}$ But I am more concerned here with trying to understand how information about variations in dollars per lives saved cost-benefit ratios conceptually relates to priority setting claims.

A stringency concern seems to undergird the constant reference to the variance in private sector dollars spent per statistical life saved in the regulatory reform literature. Regulatory reformers apparently believe that the private sector dollars spent per life saved should be reasonably even across regulatory programs. Regulatory reformers regularly claim that the Morrall table shows poor priority 
setting. ${ }^{158}$ But they have never explained what this table has to do with priority setting or why it supports the need for CBA. The table has no obvious connection to government priority setting. It does not address ordering or establish that any particular problem should be added to or subtracted from government's agenda. Rather, the table seems to suggest that some regulations are too stringent.

In the next part, I attempt to link priority setting with the stringency concerns suggested by the Morrall able. I will only partially succeed. My strained and limited success will, in turn, generate some insights into the regulatory reform debate's emphasis on CBA.

\section{Stringency, Priority Setting, and CBA-Based Regulatory Reform}

Stringency seems to have little to do with government priority setting. For example, let us assume that we agree that government should regulate problems in order of their danger to society. Government can follow this principle and still regulate too weakly or too stringently. Similarly, the government can have its ordering priorities completely wrong and regulate perfectly, but in the wrong order. This is true no matter what criteria we use to sort good from bad regulation.

Similarly, the government can select the most important problems for action and still regulate the right problems stupidly. The government can also select less important problems for action and regulate

\footnotetext{
158 See e.g. Cass R. Sunstein, Informing America: Risk Disclosure, and the First Amendment, 20 FlA. St. U. L. Rev. 653, 657 (1993); 141 Cong. REC. S2042 (daily ed. February 2, 1995 ) (statement of Senator Murkowski) (arguing that regulatory priorities are often a result of "overreaction."); Regulatory Reform: Hearings on $S .343$ Before the senate Comm. on the Judiciary, 104th Cong. 87, 89 (1995) (statement of Cass R. Sunstein).
} 
these problems appropriately, while neglecting more important problems. Again, this is true regardless of what criteria we use to sort good from bad regulation.

The first part of this article, however, noted that government regulations can affect private sector resource allocation. This provides the key to trying to understand the regulatory reformers' use of stringency concerns to support the existence of serious defects in priority setting. This part analyzes this connection between stringency and private resource allocation and then explains the implications of that analysis for the regulatory reform debate, especially as it pertains to CBA.

\section{A. Stringency and Private Priority Setting}

Government regulations typically generate private sector compliance expenditures. Private companies must get the money to pay for these expenditures from somewhere. If possible, they will raise prices and extract the money from their customers.

\section{Consumer Allocation}

Raised prices may mean that the regulated producers' customers may pay more for the producers' products and have less money to spend on other goods and services. ${ }^{159}$ This means that regulation, in effect, may cause consumers to allocate more resources to regulated goods and services and less to other goods and services.

It seems a little strained to view this reallocation of consumer monies as a form of regulatory priority setting, i.e. as an activity establishing priorities among various threats to public health and safety.

\footnotetext{
159 This assumes that consumers' budget constraints remain constant. See Hal R. Varian, Intermediate Economics 4 (3rd ed. 1993).
} 
The consumer may have the same priorities as before the regulation. ${ }^{160}$ And she may make purchase decisions that do not involve her in any decisions about health and safety at all.

Assume that an automobile manufacturer raises its car prices because of regulation. Let us suppose that a consumer, call her Sue, longs to own one of this company's cars. Surely, she values the car as highly after the price increase as she did before it; her desire remains undiminished. ${ }^{161}$ But the added cost may make it harder for her to buy car.

On the other hand, purchasing the car at the raised price may change the list of tasks she can accomplish. She could have bought the car and still gone on vacation before the regulation. Now, however, she may not have the money to pay for her vacation because of the raised price (I am assuming an unusually expensive regulation). ${ }^{162}$ This invites the question of whether the regulation has changed her selective priority setting.

Priority setting usually refers only to voluntary selection. When prices rise, our wealth diminishes and we must make do under tighter constraints. But we usually do not speak of added constraints as something that changes our priorities. We recognize that priority setting takes place in a context of constraints. Indeed, priority setting exists precisely because of constraints. If we had all of

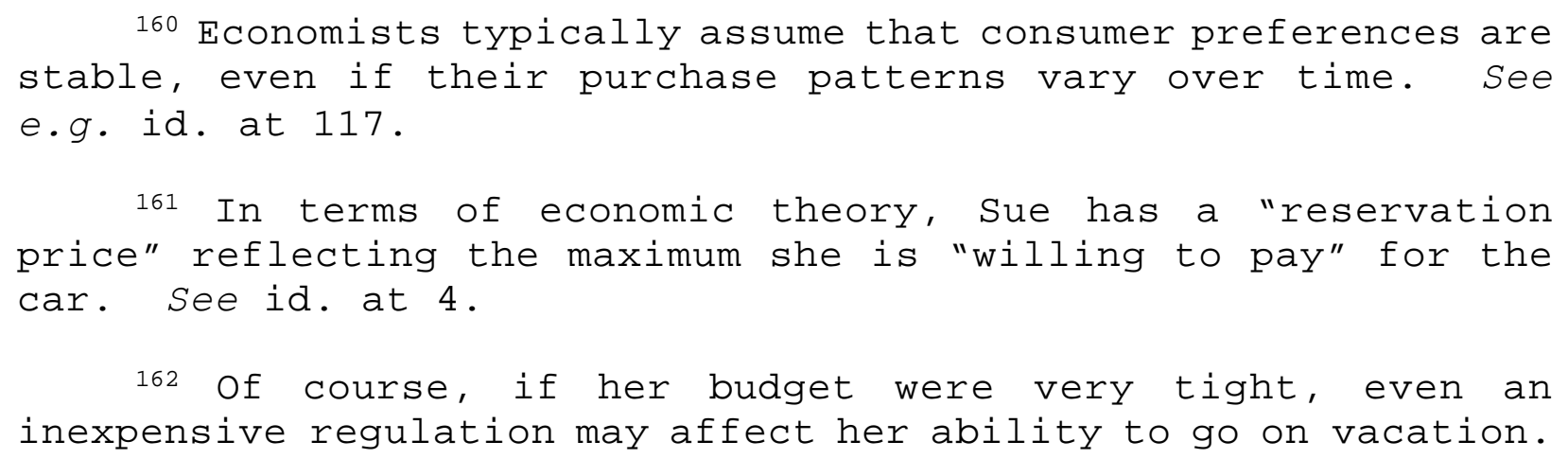


the time in the world, we might do everything. Since we do not, we must leave some tasks undone. Constraints may make priority setting more important, but that does not mean the constraints change our priorities.

Sue must carry on priority setting within stricter budgetary constraints. Perhaps her activities change but her priorities have not.

This contrasts with her own decisions about how to allocate her resources within given restraints. For example, if Sue decides to work fewer hours in order to spend more time at home with her young child, this decision might reduce her wages and force her to forego her vacation. This decision involves secondary priority setting, because she makes the decision about resource allocation that forces the change in tasks.

Suppose, however, that Sue decides not to buy the car, because the raised price makes it impossible for her to go on vacation and buy the car. ${ }^{163}$ Again, her priorities have not changed in any obvious way, but her tasks have changed. She valued the vacation more than the car all along. The price change the regulation induces, however, has made it impossible for her to avoid choosing between her priorities. 
Clearly regulation reduces her economic welfare. ${ }^{164}$ But characterizing welfare reduction as a form of regulatory priority setting seems strained at best.

If we assume that the regulation imposes a very great cost for a very meager benefit, an economist would characterize the regulation as inefficient. ${ }^{165}$ This might cause economic theory to disapprove of the regulation causing our consumer to pay more for her car. ${ }^{166}$ But this disapproval has little relationship to Sue's priorities.

When regulatory reformers use examples that rely upon consumer opportunity cost problems to illustrate their concern for poor priority setting, they are using priority setting in a non-obvious way that may mislead their readers. ${ }^{167}$ The loss of the car really is an opportunity cost problem linked to allocative efficiency concerns. Whenever we purchase something we lose an opportunity to purchase something else. ${ }^{168}$ Economists refer to this loss as an opportunity cost. ${ }^{169}$ It exists with or without government priority setting, in the sense of ordering and selection. The cost of regulatory compliance,

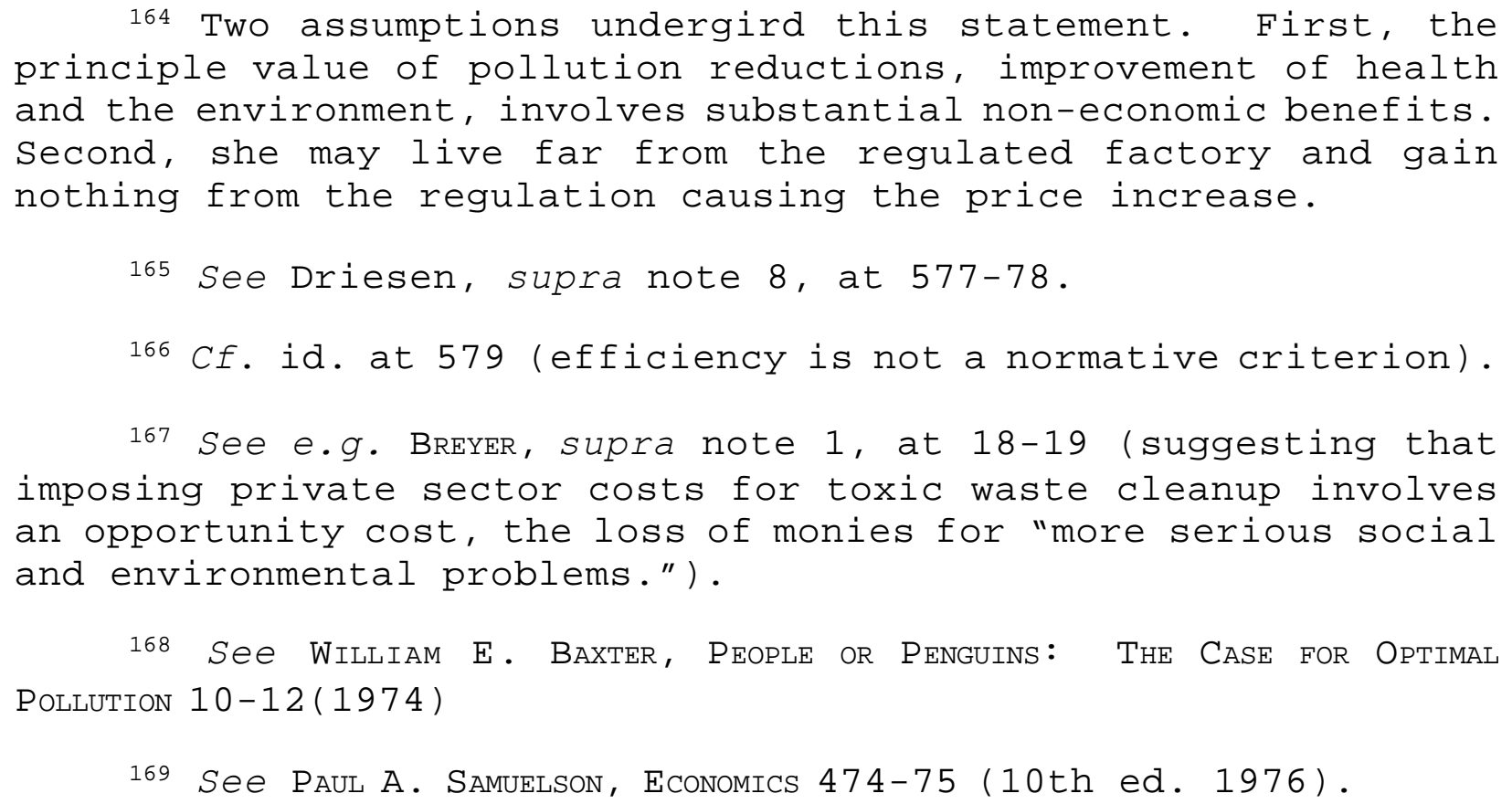
principle value of pollution reductions, improvement of health and the environment, involves substantial non-economic benefits. Second, she may live far from the regulated factory and gain nothing from the regulation causing the price increase. 
like any other cost, carries with it an opportunity cost. ${ }^{170}$ The priority setting regulatory reformers, however, do not object to the generation of opportunity costs when regulatory benefits exceed costs. Hence, the real heart of the problem here is allocative efficiency, not opportunity cost. ${ }^{171}$ The reference to opportunity cost problems as priority setting problems obscures what is at stake.

\section{Producer Allocation}

Perhaps our car manufacturer fears that raising the price will cause Sue and others to forego purchasing the car. The manufacturer may then forego the price rise and eat the cost. ${ }^{172}$ The manufacturer will then have to allocate more of its own funds to environmental protection and less to designing new products, paying workers, enriching CEO's, or paying dividends to shareholders. Again, this forces a reallocation of resources. While one can construct an argument for characterizing this as priority setting, it really seems like the involuntary imposition of a cost, with a secondary allocative impact. The theory of allocative efficiency captures this precisely, describing this as priority setting captures this in a strained way or not at all.

\footnotetext{
170 See Baxter, supra note 168, at 10-12

171 See id. at 11-12 (defining optimal pollution).

172 Producers cannot pass production price increases on to consumers for highly price elastic goods because charging more will simply cause consumers to substitute other products. See Driesen, supra note 8, at 568 n. 100 .
} 


\section{Private Allocation's Secondary Effects}

Thinking about this forced reallocation problem concretely clarifies related regulatory reform arguments. It becomes clear that the consequences regulatory reformers link to prioritizing defects have a more problematic and attenuated relationship to stringency than regulatory reformers suggest.

For example, regulatory reformers link poor government priority setting, defined mostly by reference to overly stringent regulation, with a failure to seize opportunities for cost-effective life saving measures, such as a more vigorous program of child vaccination. ${ }^{173}$ Regulatory reformers do not explain how relaxing even ridiculously stringent government regulation would increase the funding of childhood vaccination programs, or any of their other preferred public health programs. ${ }^{174}$

Our car company, if freed from the expensive regulation hypothesized, would realize greater profits or invest more in its own business in some fashion. ${ }^{175}$ This would not directly increase child vaccination. If the car company's reduced regulatory cost lowered the price of the car, she might buy the car and go on her vacation. It's a bit of a stretch to assume that she would contribute to funding childhood vaccinations. Professor Donohue claims that regulatory expenditures may "curtail private

\footnotetext{
173 See e.g. Breyer, supra note 1, at 19, 67 (suggesting a need for increased spending on childhood vaccinations, prenatal care, and mammograms).

174 See e.g. id. at 67. Cf. McGarity, supra note 1, at 34 (if cost-benefit decisions would eliminate waste, "no vehicle exists to channel the savings to • . . deserving social programs")

175 See McGarity, supra note 1, at 35 (regulated companies will devote the savings realized because of CBA to "things that make their shareholders happy.")
} 
wealth-creating investments and personal expenditures on health promotion and lifesaving." ${ }^{\text {"176 }}$ But relaxing regulatory requirements greatly increases the chance that the money that would have been spent on compliance will never be spent to save lives, but will instead be used to enhance wealth. ${ }^{177}$

The conceptual problem at the root of this involves conflating private and public resources. ${ }^{178}$ The concern about childhood vaccination might support an argument to divert public funds from EPA (or some EPA programs) to child vaccination programs. ${ }^{179}$ But childhood vaccinations have relatively little relationship to decisions about regulatory stringency. Relaxing stringency would free up more private resources to pursue private ends.

Decisions to regulate weakly would not necessarily free up any agency resources to fund other government priorities. The stringency of a regulation has no necessary relationship to the amount of government money devoted to its promulgation and enforcement.

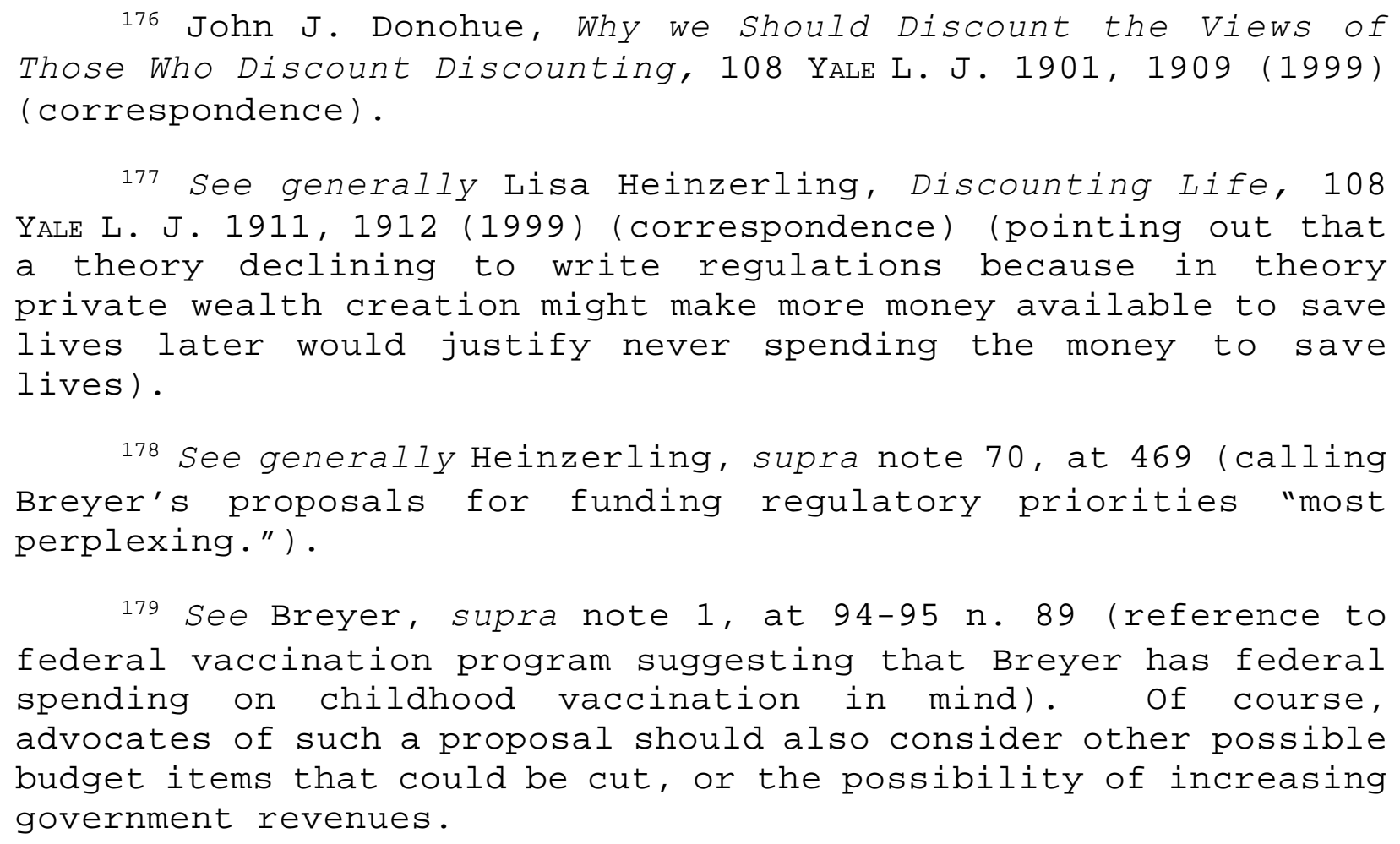


One can, however, construct elaborate theories linking regulatory stringency to childhood vaccinations. Perhaps overly stringent regulation constrains wealth creation and therefore makes tax levies to support childhood vaccinations more difficult. This, however, seems very strained.

Government spending as a percentage of GDP has fallen markedly over the last decade and a half. ${ }^{180}$ This suggests that stringent regulation cannot explain failure to adequately fund childhood vaccinations and less stringent regulation would not improve vaccination programs. Regulatory reforms never place regulation into a macroeconomic and political context to see whether the attenuated causation chains implicit in their arguments is plausible. ${ }^{181}$

A similar failure to look seriously at which resources get allocated through which decisions bedevils other regulatory reform arguments. For example, Breyer, Sunstein, and many others discuss the possibility that increased regulatory costs can lead to death, for example, as workers displaced by high regulatory costs commit suicide and die of heart attacks. ${ }^{182}$ The linking of high regulatory cost to

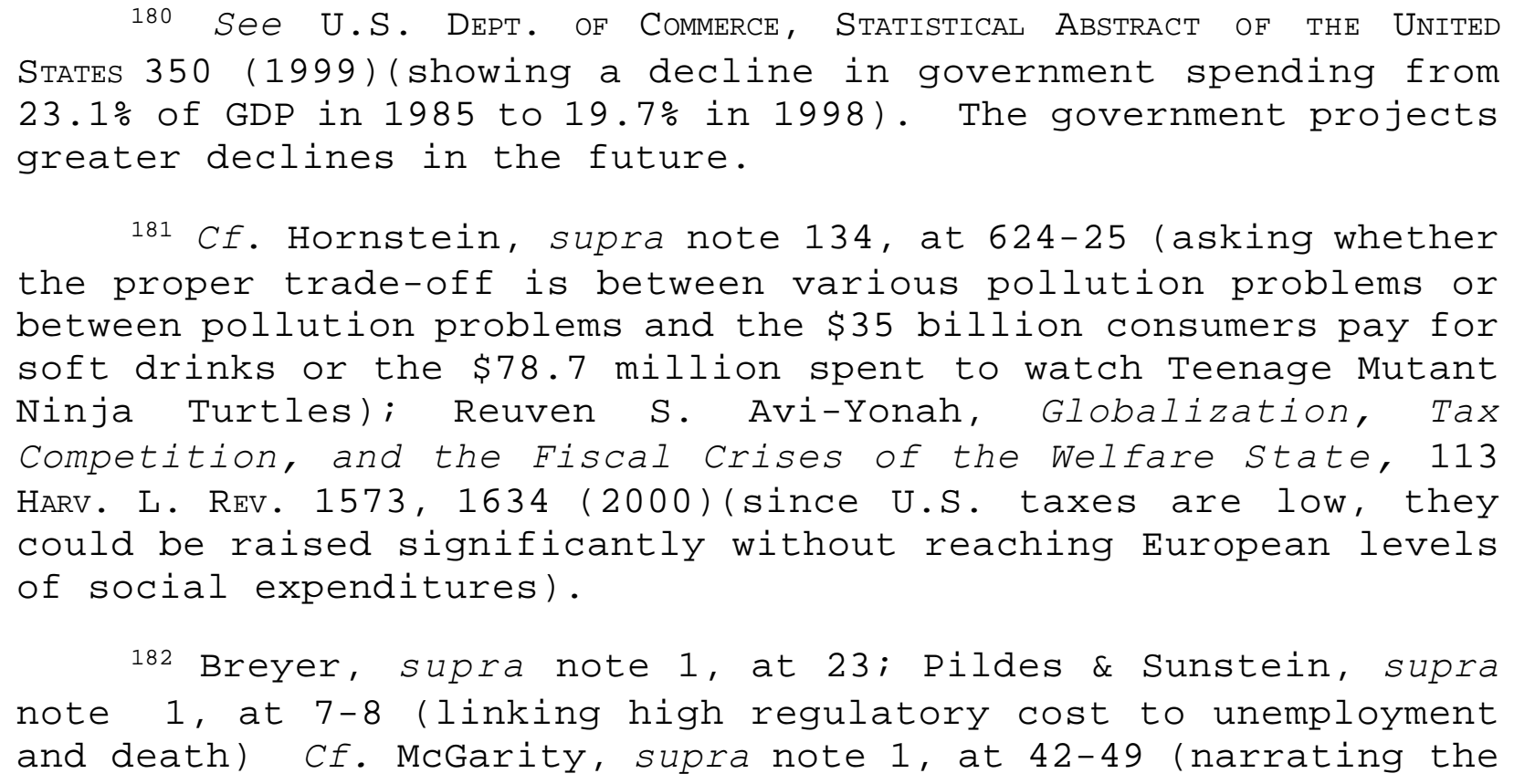
between pollution problems and the \$35 billion consumers pay for soft drinks or the $\$ 78.7$ million spent to watch Teenage Mutant Ninja Turtles); Reuven S. Avi-Yonah, Globalization, Tax Competition, and the Fiscal Crises of the Welfare State, 113 HARV. L. REV. 1573, 1634 (2000) (since U.S. taxes are low, they could be raised significantly without reaching European levels of social expenditures).

182 Breyer, supra note 1, at 23; Pildes \& Sunstein, supra note 1 , at 7-8 (linking high regulatory cost to unemployment and death) Cf. McGarity, supra note 1, at 42-49 (narrating the 
job loss has been enormously influential politically; the 104th Congress' principle vehicle for CBAbased regulatory reform bore the title, "Job Creation and Wage Enhancement Act of 1995."183

High regulatory costs, however, can create jobs by forcing companies to hire people to prevent pollution. ${ }^{184}$ Regulations impact upon employment depends, not upon the ratios of costs to benefits, but upon the distribution of costs. ${ }^{185}$

Environmental regulation has caused a small net increase in jobs. ${ }^{186}$ Furthermore, as I have demonstrated elsewhere, a cost-benefit criterion does not separate job destroying from job creating regulation. ${ }^{187}$ Overly stringent regulation, as defined by regulatory reformers, may increase jobs by forcing companies hoping to downsize to hire workers to install pollution control devices. ${ }^{188}$

While stringency does affect the allocation of private sector monies, describing stringency decisions as a form of priority setting simply obscures what is at stake. It leads to arguments that conflate the allocation of private monies with the allocation of government revenues. This, in turn fuels very misleading arguments for regulatory reform.

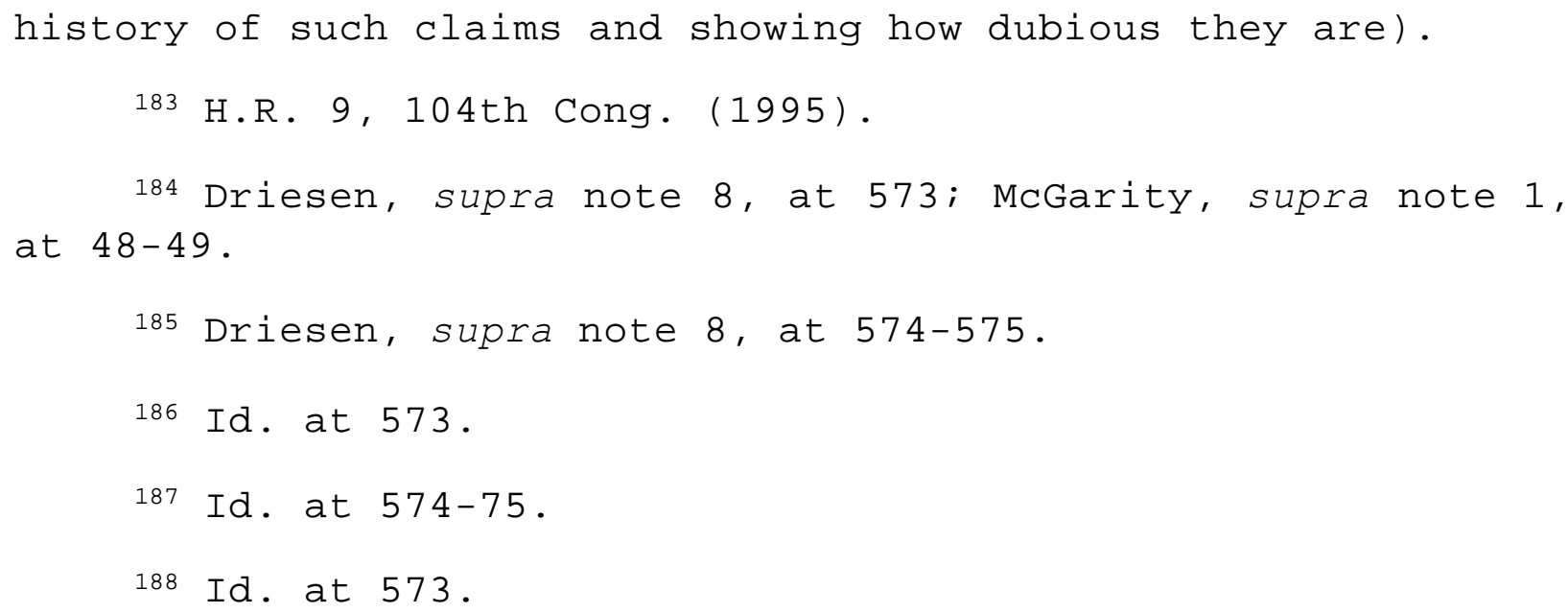


My argument decoupling priority setting from stringency, however, has limits. An analyst can plausibly think of every decision to spend any money as a "prioritizing" decision. Indeed, it is possible to think of every single action any actor takes as prioritizing, since in a static world of limited resources every use of any resource limits some other use of that resource. But defining priority setting in such broad terms makes discussion of priority setting rather meaningless, since everything becomes priority setting. Furthermore, this everything is priority setting approach is basically misleading. The world we live in is not static, as the jobs discussion suggested. ${ }^{189}$ Furthermore, while every use of a resource may involve some opportunity cost in related areas, it may leave some other potential uses of resources completely unaffected. Therefore, understanding which pools of resources are involved is important to serious thinking about secondary priority setting. The framework developed in this article more meaningfully illuminates the meaning of priority setting and its implications for reforming legal institutions than an "everything is priority setting" approach.

\section{B. Variations in Dollars Per Life Saved}

The variation in dollars per life saved depicted in the Morrall table may reflect variations in the stringency of regulatory programs. ${ }^{190}$ The analysis above suggests that viewing stringency and priority setting as related is misleading. This implies that linking the Morrall table to poor priority setting may involve some conceptual confusion.

Since the regulatory reformers offer no rationale linking inconsistent stringency to priority setting, I will try to construct one. Regulatory reformers seem to view all private sector resources as

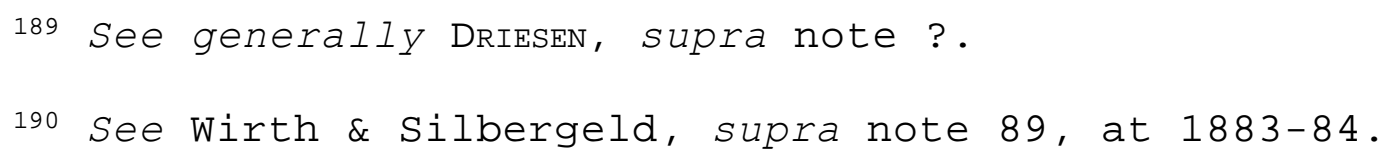


fungible assets available for deployment to all conceivable health and safety projects. ${ }^{191}$ Government through its stringency determinations allocates this money to various societal problems. Allocating too much money to trivial problems and not enough to important ones could involve poor priority setting.

I have explained, however, that not all allocation decisions function as priority setting decisions. Can a set of stringency determinations involve secondary priority setting? Decisions about stringency do not directly determine the timing of regulation, so this kind of allocative decision has little relationship to ordering. Stringency determinations can only affect selection in the rarest of cases; if the agency decides not to limit the activity it is regulating at all (an extreme version of a lax regulation), this may involve a secondary selection. ${ }^{192}$ But most decisions about stringency will not function as secondary selection decisions either. Hence, inconsistent stringency determinations, while they affect allocation, do not generally affect priority setting in its most commonly understood modes of ordering and selection.

Inconsistent stringency might involve what I have called a performance allocation, a decision to do some jobs well and others less well. I will let the reader decide whether performance allocations should be considered priority setting at all. But clearly, it would be helpful to distinguish this from ordering and selection, the most common forms of priority setting.

\footnotetext{
191 See Breyer, supra note 1, at 12-18 (following a discussion of private sector regulatory expenditures with statements about the "nation" spending too much "to buy a little extra safety"); Sunstein, Foreword, supra note 1, at (discussing misallocation of "resources for risk reduction").

192 Interview with Terry Davies, Resources for the Future (May 15, 2000).
} 
My attempt to link stringency and priority setting, however, suffers from numerous problems.

Private sector funds do not form a fungible pool of resources that a regulating agency can allocate to our most pressing regulatory priorities, so the first assumption made in trying to link stringency to priority setting is suspect. While government may require chemical plants to clean-up their own pollution, government cannot require the owners of chemical plants to improve automobile safety through better designed passive restraints, even if this would save more lives than control of toxic pollution from chemical plants. ${ }^{193}$

Stringency determinations do not reallocate private compliance resources among regulated industries. A decision to regulate toxics at a chemical plant weakly allows the company to devote more money to chemical manufacturing, it does not create more funding for auto safety. Similarly, a decision to regulate auto safety strictly, does not reduce government opportunities to demand stringent reductions from chemical plants. Hence, stringency determinations have very little or no secondary impact on cross-program regulatory priority setting. ${ }^{194}$

Finally, the view of this as a form of performance allocation seems odd, because this does not involve one actor performing some tasks well and others less well. Rather, this involves the government

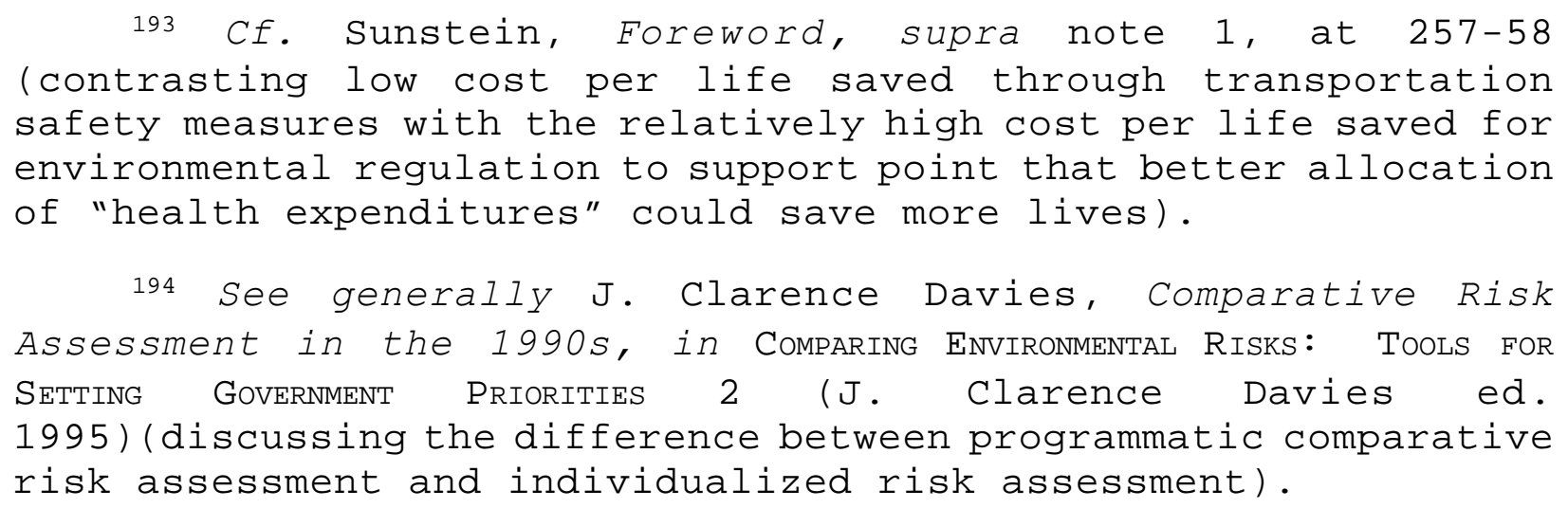


demanding a lot from some companies, while demanding less from others. It seems that characterizing inconsistent stringency as "priority setting" simply adds confusion, even if one accepts the concept of performance allocation as a kind of priority setting.

Even if thinking of stringency determinations as a form of priority setting somehow aids analysis, it is not clear why variations in lives saved shows poor priority setting. Regulatory reformers think that dollars per lives saved should be somewhat even across regulatory programs. ${ }^{195}$ They do not explain why this should be so.

One would not expect regulatory programs to produce even approximately even dollars per lives saved costs. Our regulatory system, like the common law preceding it, is based on the assumption that people must take some responsibility for the harms they cause. ${ }^{196}$ Some harms cost more to remedy than others. ${ }^{197}$

Furthermore, the regulatory system, again like the common law system, sometimes takes equity into account in deciding how strict a compliance regime to impose on companies. ${ }^{198}$ Some companies

\footnotetext{
195 See Breyer, supra note 1, at 21-22 (citing variations in dollars spent per lives saved as evidence a problem of inconsistency); 
can pay out large sums of money to take care of health and safety problems. Others would go

bankrupt if subjected to strict regulation. Agencies often take this into account in writing regulation,

with resulting unevenness in compliance cost. ${ }^{199}$ This helps avoid the kind of drastic consequences that

could occur in theory under any regime imposing any cost. While one can criticize stringency

adjustments based on equitable considerations, these adjustments hardly seem irrational.

One can, however, rationalize the expectation that dollars per lives saved should be at least

somewhat even in a stunningly straightforward way. If we assume that costs should be proportionate to

lives saved, then the departure from this norm is troubling. ${ }^{200}$ But assuming that cost-benefit

considerations should generally control the stringency of regulation involves assuming what regulatory

reformers seek to prove. ${ }^{201}$

\begin{abstract}
reprinted in Committee on Environment and Public Works U.S. Senate, I I A
Legislative History of the CleAn Air Act Amendments of 1990, at 3352 (1993) (suggesting that technology-based standards for air toxics should avoid plant closures); S. Rep. No. 101-228, at 169 (1990), reprinted in 1991 U.S.C.C.A.N. 3385, 3554 (allowing EPA not to impose very strict standards unless such standards would force a plant to discontinue operation or inflict severe economic damage on a company).

199 See Robert A. Leone, Who Profits: Winners Losers, And Government REGULATION 74, 124-25 (1986) (government will often relax standards to avoid shutting down plants, but not always).

200 See generally Heinzerling, supra note 153, at 2070 (characterizing the table as a Trojan horse laden with implicit value choices that should form the subject of debate).

201 See Nicholas A. Ashford, An Innovation-Based Strategy for the Environment, in Worst ThINGS FIRST, supra note 66, at 279 (differences in cost per life saved are not irrational unless rationality is defined "tautologically" as minimizing cost per fatality).
\end{abstract}




\section{Cost-Benefit Analysis}

Priority setting talk suggests that CBA improves government ordering and agenda selection. ${ }^{202}$ Congressional regulatory reform legislation and regulatory reformers' proposals, however, involve using CBA in rulemaking not directed at either function. Rather, they contemplate CBA's use in establishing each regulations' stringency. ${ }^{203}$ This kind of rulemaking has little to do with primary government priority setting.

\section{CBA to Improve Primary Priority Setting}

CBA could perform a role in primary ordering and selection activities. Congress could consider CBA in establishing rulemaking deadlines and EPA could consider CBA in establishing schedules and priorities, such as the national priorities list under superfund and the schedule for air toxics regulation under the Clean Air Act.

Most regulatory reformers say nothing about what principles should govern ordering or selection in advance of stringency determinations, probably because confusion about the meaning of

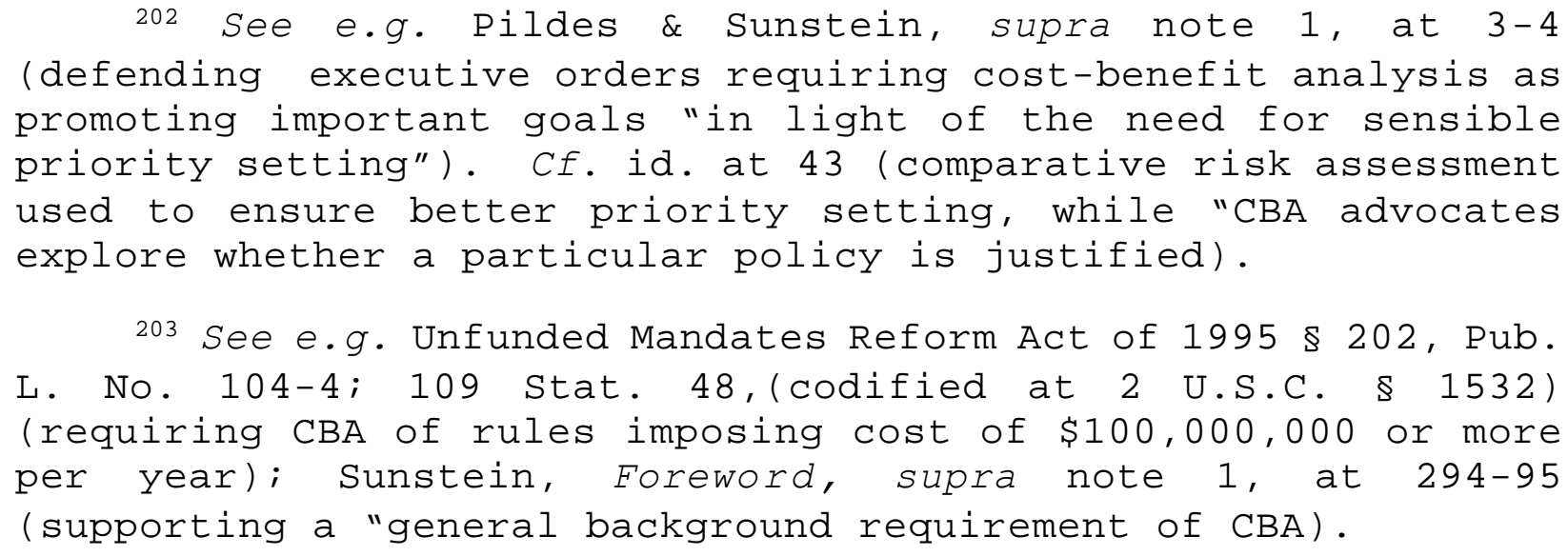


priority setting obscures this issue. ${ }^{204}$ This question of principles matters, because analysis should focus on factors relevant to the principles governing a decision. ${ }^{205}$ Sunstein and Breyer say little about whether we should employ a worst things first, simplest to regulate first, more favorable cost-benefit ratios first ordering principle, or some other principle. Careful students of comparative risk assessment recognize that priority setting involves normative choices and a rich set of potentially relevant factors. ${ }^{206}$ Pro-CBA prioritizing regulatory reformers, lacking a clear concept of priority setting, often confuse worst things first and most favorable cost-benefit-ratios first principles. Mathew D. Adler and Eric Posner, for example, claim that "CBA helps establish priorities."207 They state that "one might use

204 Cf. W. Kip Viscusi, Regulating the Regulators, 63 U. CHI. L. REV. 1423, 1458 (1996) (favoring cost-benefit principles, but conflating selecting a regulation, a stringency determination, with selecting targets of regulation, i.e. selection).

205 See Driesen, supra note 8, at 609.

206 See Hornstein, supra note 134. Cf. M. Granger Gordon, Quantitative Risk Ranking: More Promise than the Critics Suggest, in Worst THINGS FIRST?, supra note 66, at 135 (arguing for such a cost-benefit based priority ranking but recognizing that this involves a normative choice and would be difficult to implement). EPA's Unfinished Business Report, which Breyer, Sunstein, and nearly every other regulatory reformer cites, recognizes a rich set of factors as potentially relevant to priority setting. EPA, supra note 65, at 2-3. These factors include not just costs and benefits, but also the benefits to society of the activities giving rise to a risk, the feasibility of effective control, political and legislative support for action, EPA's ability to make a better contribution than other entities, and intangible aspects of risk that people find important. Id. For that reason, EPA viewed its own report's focus on comparative risk as only a first step in figuring out how to set better priorities.

207 See Mathew D. Adler \& Eric A. Posner, Rethinking CostBenefit Analysis, 109 Yale L. J. 165, 175 (1999). 
CBA to rank projects by seriousness." 208 But information about the cost of regulation is irrelevant to ranking projects by the seriousness of health risks. One can simply compare the health risks. This involves comparative risk assessment, not CBA. ${ }^{209}$ Sunstein seems to recognize this distinction between comparative risk assessment and CBA, but appears similarly confused when he cites a provision of a bill requiring $\mathrm{CBA}$ in regulations imposing large costs on private companies (i.e. determining stringency) as evidence of Congressional interest in worst things first principles and comparative risk assessment. $^{210}$

Furthermore, evaluating the relative seriousness of an environmental problem (the kind of analysis suggested by a "worst things first" principle) involves a different analysis than evaluating the benefits of a proposed regulation. Evaluating the seriousness of an existing problem involves determining the consequences of existing levels of pollution, i.e. baseline conditions. Evaluating the benefit of a proposed regulation involves comparing this baseline to conditions after implementation of a proposed regulation.

Analysts who wish to think seriously about ordering should take into account the relationship between ordering criteria and selection. Increasing the complexity of ordering or selection decisions raises an issue about whether priority-setting exercises should consume a major portion of the

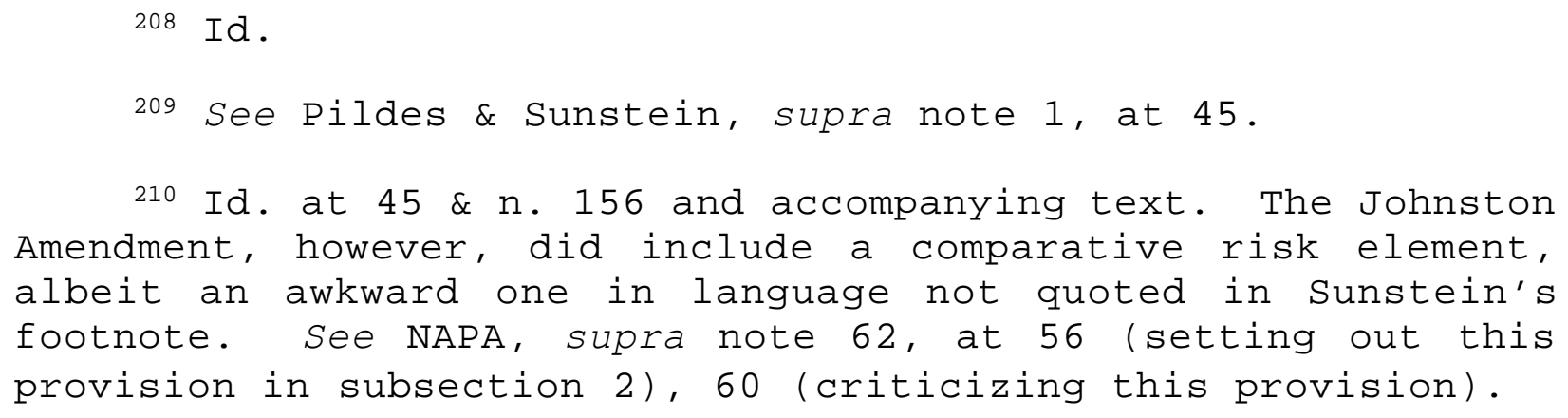


resources to accomplish actual change in the real world. ${ }^{211}$ A long complex ordering or selection process involves a secondary allocation of government resources that limits the scope of regulatory programs. Yet, regulatory reformers say little about CBA's role in ordering and selection, which suggests that their concerns lie elsewhere.

\section{CBA and the Stringency of Environmental Regulation}

Since those reformers who support CBA favor introducing it into individual rulemakings to determine stringency, support for CBA requires a case for its use in determining the stringency of regulation, rather than priority setting. I have addressed the question of whether CBA should influence or determine the stringency of regulation elsewhere and plan to focus the discussion here only on those elements that the theory of priority setting brings more clearly into focus. ${ }^{212}$

211 Dale Hattis \& Robert L. Goble, Current Priority-Setting Methodology: Too Little Rationality or Too Much?, in Worst things FIRST?, supra note 19, at 123 (opining that the "priority-setting enterprise" should not "consume a major portion of the resources available to accomplish real change in the real world."). See generally Eagle Picher-Industries V. EPA, 759 F.2d 905, 917 (EPA briefs reflect concern that the need to repeatedly defend its priority ranking under superfund would take funds away from cleanup). Regulatory reformers also do not discuss the fact that ordering exercises sometimes shape a schedule going out a decade or more for regulations. See e.g. 42 U.S.C. \$ 7412 (e)(1). This raises issues about information about control costs, which is necessary for CBA, becoming outdated. See David M. Driesen, Should Congress Direct the EPA to Allow Serious Harms to Public Health to Continue?: Cost-Benefit Tests and NAAQS under the Clean Air Act, 11 Tulane Envt'l L. J. 217, 227230 (1998) (explaining how this difficulty would make CBA of national ambient air quality standards impractical). CBA could transform ordering, a step that directly brings no environmental improvement, into a long drawn out task.

$$
212 \text { See Driesen, supra note } 8 \text {. }
$$


Requirements for CBA in rulemaking establishing regulatory stringency may have a secondary effect upon government priority setting, reducing the scope of government public health protection. CBA will increase the cost to the government of carrying out regulatory programs, ${ }^{213}$ and therefore should make adequate funding of other programs protecting public health less likely. A requirement for CBA forces a government agency to spend more money developing each regulation, because of the need to spend time and energy comprehensively analyzing regulatory costs and benefits. ${ }^{214}$ This means that CBA augments agency costs. Conversely, a very simple but strict statutory mandate might consume few agency resources, but facilitate strict regulation requiring substantial private investment in pollution control. ${ }^{215}$ CBA may make adequate funding for competing government health and safety

\footnotetext{
213 See id. at 601-605; Bruce A. Ackerman \& Richard B. Stewart, Reforming Environmental Law, 37 StAn. L. Rev. 1333, 1352 (1985) (citing "problems of limited information and excessive regulatory complexity"); Sunstein, Foreword, supra note 1, at 300 (calculation of costs and benefits involves imposition of "large information burdens on government).

214 See e.g. Thomas O. McGarity, The courts and the Ossification of Rulemaking: A Response to Professor Seidenfeld, 75 TEXAS L. REv. 525, 541-549 (1997) (describing the analytical burdens imposed on EPA through judicial imposition of a costbenefit test); McGarity, supra note 1, at 50 (cost-benefit analyses for major rules have cost millions of dollars apiece in consulting contracts alone); THOMAs O. MCGarity, Reinventing Rationality: The Role of Regulatory AnAlysis in the Federal Bureaucracy at 5 (1996) (referring to "comprehensive rationality").

215 Adler \& Posner, supra note 206, at 225 (CBA "more expensive to implement" than unidimensional procedures). Adler and Posner, however, "doubt" that the criteria of technological feasability is cheaper and easier to implement than CBA. Id. at 232 n. 179. This doubt is ill-founded for the simple reason that CBA requires consideration of almost all of the factors relevant to the technological feasability inquiry plus health and environmental factors that are far more difficult to assess
} 
priorities, such as more childhood vaccinations, less likely. If Congress provides adequate funding to carry out the analysis properly, less government money is available to pay for childhood vaccinations.

So far, however, Congress has not provided the enormous increase in analytical resources needed for a cost-benefit state to operate. ${ }^{216}$ This means that the government will likely have to contract its regulatory agenda in order to complete rulemaking with increased analytical burdens.

than technological feasability. See e.g. 42 U.S.C. \$ 7412 (d) (2); Michigan V. Thomas, 805 F.2d 176 (6th Cir. 1986) (describing test for reasonably available control technology); Natural Resources Defense Council V. EPA, 824 F.2d 1146 (D.C. Cir. 1987) (en banc) (describing test for health-based air toxics standard); Lead Industries Ass'n V. EPA, 647 F.2d 1130 (D.C. Cir. 1980), cert. denied, 449 U.S. 1042 (1980) (test for health based air quality standards); National Lime Ass'n v. EPA, 627 F.2d 416, 416 (D.C. Cir. 1980) (remanding to collect additional data because record had inadequate support with respect to "achievability" of performance standards). CBA requires assessment of costs and averted harm from possible pollution control measures. In order to assess the cost of achieving a given level of pollution reduction, an agency must understand the technological options available for meeting a given pollution reduction requirement in order to estimate cost. Furthermore, for the judgment about cost to be non-arbitrary, it must involve considerations of technologies that actually can be implemented (a feasability judgment similar to that involved in technology-based regulation).

CBA supplements this technological cost analysis with a demanding valuation of "benefits," requiring evaluation of the precise health and environmental effects of discrete pollution levels. Because of gaps in the information available about pollutants' effects this is almost always a very difficult and uncertain inquiry. In any case, the view that CBA is simpler than technological feasability conflicts with the views of almost all experts in the field.

216 See Natural Resources Defense Council, Breach of Faith: How the Contract's Fine Print Undermines America's Environmental Success 6-7 (1995) (EPA Administrator Carol Browner concluded that EPA compliance with H.R. 9 would require 980 new employees and more than \$220 million). 
This involves a form of secondary selective priority setting by Congress; its decision to devote more resources to analysis requires selection of fewer items for regulation.

Sunstein relies heavily upon priority setting talk to justify CBA, as I have already shown. Our existing regulatory system, not being based on allocative efficiency and cost-benefit analysis, produces uneven dollars per lives saved numbers. By labeling departures from allocative efficiency a prioritizing defect, he avoids having to defend the notion that the regulatory system should reflect an efficiency norm in the first instance. ${ }^{217}$

217 See Sunstein, Foreword, supra note 1, at 253 (rejecting desirability of implementing all regulation "by reference to the principle of economic efficiency based on . . willingness to pay."). Sunstein and other regulatory reformers use other devices to avoid confronting efficiency. For example, sunstein suggests understanding $\mathrm{CBA}$ as a desirable effort to replace "absolutism" with "balancing." Id. See also Adler \& Posner, supra note 206 (developing a desire-based theory as an alternative to a preference -based theory for CBA). This understanding, however, is untenable. The regulatory reform legislation and Sunstein's own proposal apply CBA not to the tiny number of statutory provisions forbidding consideration of costs, but to the overwhelming majority that already authorize consideration of cost. See id. at 300 (calling for cost-benefit balancing in statutes currently based on health or technology); Unfunded Mandates Reform Act of 1995 \$ 202, Pub. L. No. 104-4; 109 Stat. 48, (codified at 2 U.S.C. \$ 1532); 42 U.S.C. \$ 7412 (d) (2); Michigan V. Thomas, 805 F.2d 176, 181 (6th Cir. 1986) (reasonably available control technology requirement includes cost consideration); American Textile Manufacturers Institute Inc. V. Donovan, 452 U.S. 490, 540 (1981)(CBA irrelevant to feasability determination, but costs are taken into account); NRDC V. EPA, 824 F.2d 1146 (D.C. Cir. 1987) (en banc) (interpreting Clean Air Act's requirement that regulations addressing hazardous air emissions provide an "ample margin of safety to allow consideration of cost in creating the ample margin). Cf. Lead Industries Ass'n V. EPA, 647 F.2d 1130 (D.C. Cir. 1980), cert. denied, 449 U.S. 1042 (1980) (cost not taken into account in setting national ambient air quality standards 
Cass Sunstein increasingly emphasizes CBA's value as a corrective to public misperception of risk. ${ }^{218} \mathrm{He}$ does not show that public misperception of risk explains the discrepancies in dollars per lives saved that disturb him or any other set of claimed regulatory defects. Hence, there is a mismatch between Sunstein's reasons for reform and the remedy he proposes. ${ }^{219}$

A variant on Sunstein's argument about public misperception of risk stripped of its reference to priority setting might form the basis for a coherent argument for CBA. An argument that regulation is usually too stringent and the regulatory system too vast because of public misperceptions of risk would indeed support CBA in at least some rulemaking. ${ }^{220}$ Since CBA would serve the purpose of reducing the scope and stringency of rulemaking, it would help correct such a problem. ${ }^{221}$ An argument that we (NAAQS)); American Trucking Ass'n v. EPA, 175 F.3rd 1027, $1044-$ 1045 (D.C. Cir. 1999), modified, 195 F.3rd 4 (2000), cert. granted, 68 USLW 3496; 68 USLW 3566 (characterizing EPA's claim that its ambient standard did not directly regulate small business, because states determine the emission limitations on sources as "incontestable"); Union Electric V. EPA, 427 U.S. 246 , 266 (1976) (states may consider cost in achieving the NAAQS).

218 See e.g. Timur Kuran \& Cass R Sunstein, Availability Cascades and Risk Regulation, 51 Stanford L. Rev. 683 (1999); Sunstein, Cognition, supra note 1 .

219 See generally stephen Breyer, Analyzing Regulatory Failure: Mismatches, Less Restrictive Alternatives, and Reform, 92 HARV. L. REV. 549 (1979).

220 Cf. Sunstein, Cognition, supra note 1, at 22 (disparities in dollars per life saved "do not establish pervasive overregulation, but they do support the view that resources are misallocated").

221 See McGarity, supra note 1, at 77-78 (CBA will help industries avoid, slowdown, or reduce the stringency of regulation); James $\mathrm{T}$. Hamilton \& W. Kip Viscusi, The Benefits 
need to reduce the scope and stringency of the regulatory system would prove difficult to adequately to support factually. Conceptually, it should rest on a firm demonstration that public hysteria has had a pervasive pernicious effect upon agency rulemaking and that the countervailing problems of industry hysteria about cost and tendency to aggressively downplay risk is not a more serious impediment to sensible regulation. ${ }^{222}$ It should also address the possibility that less cumbersome remedies might more effectively address concerns about excessive stringency, such as provisions authorizing delisting of harmless pollutants and the consideration of certain unintended consequences. ${ }^{223}$ Furthermore, a theory that agency rulemaking should correct rather than reflect public risk perceptions would have to meet constitutional objections based on the placement of legislative authority in democratically elected legislatures. ${ }^{224}$ A debate about stringency, however, would address the questions germane to decisions and Costs of Regulatory Reform for Superfund, 16 Stan Envtu. L. J. 159, 177 (1997) (CBA would reduce the number of superfund sites remediated).

222 Cf. Wirth \& Silbergeld, supra note 89, at 1883 (pesticide residues in food are too high despite plenty of public outcry against pesticides); Heinzerling, supra note 70, at 464 (Breyer's failure to discuss industry fights to discourage regulation makes his analysis "woefully incomplete."); Clayton Gillette and James Krier, Risk Courts, and Agencies, $138 \mathrm{U}$. Penn. L REv. 1027, 1061-99 (1990) (explaining why agencies may underestimate risk).

223 See e.g. 42 U.S.C. \$ 7412 (b) (3) (authorizing deletion of substances from list of regulated hazardous air pollutants), (d) (2) (authorizing consideration of non-air quality health and environmental impacts while writing air regulations),

224 See Habicht, supra note 131, at 38 (EPA believes that people have the right to choose which risks society should care amount the most through democratic institutions). 
about increased reliance upon CBA. The discussion of priority setting has diverted attention from those questions.

\section{Conclusion}

We do not know whether we have a serious priority setting problem, because of conceptual confusion and a failure to consider the information most germane to evaluating that issue. If we do have a priority setting problem, $\mathrm{CBA}$ in rulemaking that develops regulatory standards (as opposed to regulatory schedules) will not address the problem. 